\title{
THE POLITICAL ECONOMY OF DEFORESTATION IN THE TROPICS*
}

\author{
ROBIN BURGESS \\ MATTHEW HANSEN \\ BENJAMIN A. OLKEN \\ PETER POTAPOV \\ STEFANIE SIEBER
}

Tropical deforestation accounts for almost one-fifth of greenhouse gas emissions and threatens the world's most diverse ecosystems. Much of this deforestation is driven by illegal logging. We use novel satellite data that tracks annual deforestation across eight years of Indonesian institutional change to examine how local officials' incentives affect deforestation. Increases in the number of political jurisdictions lead to increased deforestation and lower timber prices, consistent with Cournot competition between jurisdictions. Illegal logging and local oil and gas rents are short-run substitutes, but this effect disappears over time with political turnover. The results illustrate how local officials' incentives affect deforestation and show how standard economic theories can explain illegal behavior. JEL Codes: D73, L73.

\section{INTRODUCTION}

Viewed from space two great bands of green-the equatorial, tropical forests and northern, temperate and boreal forestsencircle the globe. Deforestation has been extremely rapid in tropical forests relative to their northern counterparts. One reason for this is the greater prevalence of illegal extraction, which often negates or overturns attempts to sustain forest

\footnotetext{
*We thank Pranab Bardhan, Tim Besley, Mario Boccucci, Bronwen Burgess, Ahmad Dermawan, Dave Donaldson, Claudio Ferraz, Frederico Finan, Amy Finkelstein, Andrew Foster, Jason Garred, Michael Greenstone, Elhanan Helpman, Seema Jayachandran, Lawrence Katz, Ted Miguel, Mushfiq Mobarak, Ameet Morjaria, Sriniketh Nagavarapu, Krystof Obidzinski, Subhrendu Pattanayak, Torsten Persson, Fred Stolle, Nico Voigtlaender, Pierre Yared, numerous seminar participants, and five anonymous referees for helpful comments and suggestions. We thank Angela Kilby, Zejd Muhammad, Prani Sastiono, Mahvish Shaukat, and Nivedhitha Subramanian for excellent research assistance. We thank the LSE Centre for Climate Change Economics and Policy, the Grantham Research Institute on Climate Change and the Environment at the LSE, and the National Aeronautics and Space Administration's Land Cover and Land Use Change and MEASURES programs under grants NNG06GD95G and NNX08AP33A for financial assistance. The views expressed here are those of the authors alone and do not necessarily reflect those of the World Bank or any of the many other organizations acknowledged here.

(C) The Author(s) 2012. Published by Oxford University Press, on behalf of President and Fellows of Harvard College. All rights reserved. For Permissions, please email: journals .permissions@oup.com

The Quarterly Journal of Economics (2012), 1-48. doi:10.1093/qje/qjs034.
} 
cover in tropical areas. Understanding why illegal extraction is often sanctioned or facilitated is therefore likely to be central to countering tropical deforestation.

The current importance attached to understanding the determinants of tropical deforestation stems from a growing realization that the disappearance of these forests will have impacts that extend beyond national boundaries. Globally, deforestation accounts for almost one-fifth of annual emissions of greenhouse gases, with the bulk of this coming from tropical forests. To put this in perspective, deforestation contributes more to greenhouse gas emissions than the global transportation sector and roughly the same amount of emissions as the entire United States. Tropical forests are also the most biodiverse environments on the planet, and their disappearance brings a mass extinction of species, which deprives future generations of the value associated with this genetic diversity. These dual concerns of climate change and biodiversity have served to put tropical deforestation, particularly understanding how to counter illegal extraction, toward the top of the current global policy agenda (Hansen and DeFries 2004; Stern 2006; Nabuurs et al. 2007; IPCC 2007; Kindermann et al. 2008).

The vast majority of tropical forests are owned and managed by national governments, which in turn rely on local bureaucrats and politicians to enforce national logging rules. Central monitoring of these local officials is imperfect, and these officials can (and do) allow deforestation above and beyond the amount officially sanctioned by the central government. As a result, it is not uncommon in tropical areas for the majority of the wood extracted to involve some illegal action. In Indonesia, for example, up to $60 \%$ to $80 \%$ of wood yield may involve some illegal action-much of which may be condoned in some form by these local officials (CIFOR 2004).

This article uses Indonesian data to examine the incentives faced by local bureaucrats and politicians to allow more or less logging in their jurisdictions. To guide the empirical analysis we present a simple model in which firms decide where to log, but their activities are contingent on obtaining permits (legal or otherwise) from the local district governments that enforce forest policy. In determining how many such permits to issue, districts are engaged in Cournot competition with one another within a provincial wood market. As the number of districts in a wood market increases, the Cournot framework suggests that 
the amount of wood extracted should rise and the price of wood should fall. Augmenting this simple model with a probability that district governments are punished for allowing illegal logging beyond the legal quota yields the prediction that the presence of alternative sources of rents for district governments should reduce forest extraction.

The key predictions from the model are then taken to a rich data set for Indonesia. Indonesia is, in many ways, an ideal context for such a study. Along with the Amazon and Congo basins, it contains one of the three largest stands of tropical forest in the world. Rapid deforestation places it just behind the United States and China as the third largest producer of greenhouse gases worldwide. And the unique features of post-Suharto institutions and institutional change generate plausibly exogenous variation in the incentives affecting the decision of district bureaucrats and politicians to allow more or less logging within their jurisdictions.

Since so much deforestation in Indonesia is a result of illegal logging, we cannot rely on official production statistics to capture deforestation. Instead, we use a novel data set that we constructed from Moderate Resolution Imaging Spectroradiometer (MODIS) satellite imagery which allows us to capture deforestation across the entire country. Using these data, we can detect deforestation at a 250-meter by 250-meter resolution annually for all of Indonesia from 2001 to 2008 (Hansen et al. 2009). We combine the pixel-level data on deforestation from our MODIS data with Geographic Information Systems (GIS) data on district boundaries and land-use classifications to construct a data set that captures deforestation across localities and across four land-use zones-the Production and Conversion zones where some amount of logging is legal (for specific amounts within specific concessions), and the Conservation and Protection zones (where all logging is strictly illegal).

To test the impact of the number of political jurisdictions on deforestation, we take advantage of the fact that Indonesia has experienced a remarkable increase in the number of administrative divisions over the past decade. Between 2000 and 2008, the number of districts in the main forest islands of Indonesia almost doubled, from 189 in 2000 to 312 in 2008. Exploiting the differential timing of these district splits, we estimate that subdividing a province by adding one more district increases the overall deforestation rate in that province by $8.2 \%$. The increase appears in 
both land-use zones where logging can be either legal or illegal, as well as in the land-use zones where all logging is illegal.

Though there are multiple reasons why subdividing administrative jurisdictions could increase deforestation, the evidence appears consistent with a model in which Indonesian district governments engage in Cournot-style competition in determining how much wood to extract from their forests. We show that the increase in administrative jurisdictions drives down prices in the local wood market: adding one more district to a province reduces local prices in the province by $3.3 \%$, implying a local demand elasticity for logs of about 2.3. A back-of-the-envelope calculation suggests that the magnitude of the increase in deforestation we observe is consistent with what a simple, static Cournot model would predict given this elasticity. With regard to alternative explanations, the fact that we find similar results in zones where no legal logging takes place suggests that the results are not just about changes in official policies due to changes in bargaining power of districts vis-à-vis central government. The fact that the impact of new jurisdictions on deforestation rates increases over time rather than decreases, and the fact that deforestation is not more likely to occur in the new part of the district, suggest that declines in enforcement in the illegal logging zones are not primarily driving the results.

To test for substitution between illegal logging and other sources of rent extraction, we exploit changes in a district's oil and gas revenue-sharing receipts over time. Oil and gas reserves are highly unevenly distributed across Indonesia, and the revenue sharing rules put in place by post-Suharto governments mean that the amount of revenue a district receives in a given year depends on oil and gas prices, production in own and surrounding districts, and the number of districts in the province. Consistent with the existing literature on short run substitution between alternate forms of corruption (Olken 2007; Niehaus and Sukhtankar 2009), we find that rents from illegal logging and the potential for rents from oil and gas revenue sharing are substitutes in the short run. In the medium term, however, we show that over half of this effect disappears. We provide suggestive evidence that the effect disappears over time because the higher oil and gas rents lead over time to the formation of new, higher rent-extraction political coalitions (as in Brollo et al. 2009). 
The results in this study provide new evidence on how potentially corrupt bureaucrats and politicians respond to incentives. The main results are consistent with rent maximization by local officials: as an official's market power diminishes (due to district splits), he increases the rate of rent extraction, and as alternative sources of rents increase (due to increased oil and gas revenue), so that he has more to lose from being found engaging in illegal activity in the forest sector, he decreases rent extraction. The results thus provide an example of how illegal behavior can be explained by standard economic models (as in Becker and Stigler 1974; Shleifer and Vishny 1993; Olken and Barron 2009).

The remainder of this article is organized as follows. In Section II we outline a simple theoretical framework that captures the key forces affecting the decision of district governments to permit more or less logging within their jurisdiction. Section III discusses the background on institutional change and deforestation in Indonesia and the construction of the data we use to examine these processes. Section IV examines how the splitting of districts affected deforestation, which we interpret in the light of our theoretical framework. Section V investigates whether having access to alternative sources of public finance incentivizes or disincentivizes districts to engage in logging. Section VI concludes.

\section{THEORETICAL FRAMEWORK}

We consider a context in which local government plays an important role in determining how much deforestation takes place. This occurs because local governments are responsible for regulating and monitoring the extraction of wood within their jurisdiction, so if a firm wishes to extract wood, it can only do so with the consent of local government.

We model this by assuming that there are a large number of logging firms that can choose where to log, but must obtain a (legal or illegal) permit from the district government to do so. Districts choose the number of permits to sell to firms taking the number of permits issued by other districts as given. In this context, a bribe is just the price paid for a permit beyond the legal limit. Prices are determined in equilibrium by firms' willingness to pay for the permits. The net result is that districts engage in Cournot competition with each other, so that increasing the 
number of districts increases the quantity of wood felled and decreases equilibrium prices in wood markets. The model thus captures the idea that increasing competition between political actors can drive down prices, as in Shleifer and Vishny (1993). ${ }^{1}$

We begin by specifying the firms' problem, then the problem for the district governments, and then we characterize the equilibrium. Suppose that there is free-entry for logging firms. Logging firms can log in any district they choose at a constant marginal cost $c$ per unit of wood extracted from the forest. However, to extract logs from a given district $d$, a firm needs to secure a permit from the district government, at $\operatorname{cost} b_{d}$ per unit extracted.

Suppose that in each province, there is a downward-sloping inverse demand function for wood products, denoted by $p(Q)$ where $Q$ is the total quantity of wood produced in the province. ${ }^{2}$ Each firm $f$ in district $d$ solves

$$
\max _{q_{f d}} p(Q) q_{f d}-c q_{f d}-b_{d} q_{f d} .
$$

Firms are thus willing to pay fees up to $b_{d}=p(Q)-c$ to obtain logging permits in district $d$. Free entry of firms will ensure that this holds in equality.

We assume that the head of each district government determines the quantity of permits to issue in its district and then sells the permits to firms. If a district issues more logging permits than its legal quota (denoted $\bar{q}$ ), it faces some chance that illegal activity will be detected. We denote this probability of detection as $\pi\left(q_{d}, \bar{q}\right)$, and we assume that it is positive whenever there is illegal logging, and that it is increasing in the amount of illegal logging. Note that $\pi$ depends on the decision of that district $\left(q_{d}, \bar{q}\right)$ and not the decisions of other districts. If a district head is detected, he loses all future rents associated with office, denoted $r_{d}$.

The head of each district $d$ solves

$$
\max _{q_{d}} b\left(q_{d}\right) q_{d}-\pi\left(q_{d}, \bar{q}\right) r_{d} .
$$

1. Note, though, that in this model district governments compete over quantities, whereas Shleifer and Vishny discusses Bertrand competition over prices.

2 . In our empirical setting we treat each province as a wood market and estimate downward-sloping demand curves in each market. Transport costs, the need to process logs locally before export (Indonesia bans the export of raw, unprocessed logs), and capacity constraints at local sawmills combine to generate local downward-sloping demand curves for logs in each provincial wood market. 
Substituting yields the familiar Cournot maximization problem, augmented by the probability of detection

$$
\max _{q_{d}} q_{d} p\left(\sum_{j=1}^{D} q_{j}\right)-c q_{d}-\pi\left(q_{d}, \bar{q}\right) r_{d} .
$$

The first-order condition is

$$
q_{d} p^{\prime}+p-c-\pi^{\prime}\left(q_{d}, \bar{q}\right) r_{d}=0 .
$$

Next, suppose there are $n$ identical districts in a provincial wood market, so that total quantity $Q=n q_{d}$. Rewriting and substituting $Q=n q_{d}$ yields the familiar Cournot equation, modified by the $\pi^{\prime}\left(q_{d}, \bar{q}\right) r$ term:

$$
\frac{(p-c)}{p}=\frac{1}{n \varepsilon}+\frac{\pi^{\prime}\left(\frac{Q}{n}, \bar{q}\right) r}{p},
$$

where $\varepsilon$ is the price elasticity of demand.

This equation has several implications. First, increasing $n$ reduces prices and increases forest extraction in the provincial wood market as the market becomes more nearly competitive. These are standard predictions from a static Cournot model. Note that this Cournot effect does not depend on the probability of detection (i.e., it also holds even if $\pi=0$ or $r=0$ ). Lewis and Schmalensee (1980) show that these predictions also hold in a dynamic Cournot setting, where the problem districts face is thus that of oligopolistic competition in a nonrenewable natural resource. In particular, they show that a greater number of actors in a market-in our case, more districts-leads to lower prices and greater resource extraction. ${ }^{3}$ We test both these quantity and price predictions in Section IV.

Second, there will be substitution between illegal logging and other forms of rents $r$. In particular, for a given district, if the district is in the range where $\pi^{\prime}>0$, which by assumption is whenever $q_{d}>\bar{q}$, then increasing $r$ will lead to a reduction in the quantity of wood extracted from a district, $q_{d}$. This effect

3. See Proposition 3 in Lewis and Schmalensee (1980). Note that we abstract away from tree regrowth and instead treat forests as an exhaustible natural resource. This is consistent with de facto logging practice in many tropical forests, including those in Indonesia, where virgin forests are heavily logged, and then either left in a degraded state or converted to a nonforest use, such as palm plantations. 
depends on there being a trade-off between other types of rents and wood extraction, so only holds if $\pi^{\prime}>0$. The idea that one type of corruption and other sources of rents may be substitutes will be examined empirically in Section V.

To interpret the empirical results, it is useful to derive a more explicit formula for the relationship between the quantity of deforestation and the number of districts. To do so, we need to posit a functional form for the inverse demand function. Suppose we have a constant elasticity of demand, that is, $p=\frac{a}{q^{\lambda}}$, where $\varepsilon=\frac{1}{\lambda}$. If we assume that $\pi^{\prime \prime}=0$, then substituting $p=\frac{a}{q^{\lambda}}$ into equation (2), taking derivatives, and simplifying yields:

$$
\frac{1}{Q} \frac{d Q}{d n}=\frac{1}{n^{2}-n \lambda} .
$$

This is a simple formula for the semi-elasticity of quantity with respect to the number of jurisdictions in the market, which is the parameter we estimate in the empirical work.

A critical assumption of the model is that firms need permission from only one district to conduct illegal logging. If, alternatively, firms needed to bribe multiple districts to log, the predictions would be quite different. For example, if firms needed to bribe every district between the source of the logs and the destination in order to transport logs, then increasing the number of districts could increase total bribes and decrease logging, as in Olken and Barron (2009). ${ }^{4}$ We explore the relationship between the number of jurisdictions and the total cost of logging empirically later.

\section{BACKGROUND AND DATA}

Indonesia comprises an archipelago of islands in Southeast Asia stretching from the Indian Ocean to the Pacific Ocean. It is a vast country. From tip to tip (from Sabang in Aceh to Merauke in Papua), Indonesia is 3,250 miles across; this is the same as the distance from Tampa, Florida, to Juneau, Alaska. The conditions in Indonesia are ideal for the growth of forests and without the

4. Empirically, we do not think that is the case in this context-the origin district in fact can issue fake transport permits (known as SKSHH in Indonesia) which would be difficult for downstream districts to distinguish from real permits. The key actor is therefore likely to be the district that actually controls the forest, in which case competition between districts should be the relevant force. 
involvement of humans, Indonesia would be largely covered in forest.

In this section we trace out the dramatic political changes that Indonesia has experienced in its recent past, and document how these changes have resulted in a tug of war over the control of the forest sector. We then describe the data sets that we have built to capture both institutional change and deforestation in Indonesia.

\section{III.A. Decentralization in Post-Suharto Indonesia}

The East Asian crisis brought to an end the 32-year regime of President Suharto on May 21, 1998. Suharto's departure ushered in one of the most radical reconfigurations of a modern state, combining a democratic transition with a dramatic decentralization of power. Amid fears that the multiethnic country would break apart, substantial administrative and fiscal authority was devolved to approximately 300 district governments. Off-Java regions which were rich in natural resources like forests, oil, and gas were particularly strident in their demands for more of the revenue from their extraction to accrue to them (Hofman and Kaiser 2004). The decentralization laws, which were passed in 1999 and took effect in 2001, devolved approximately $25 \%$ of the national budget to the districts in the form of block grants and dramatically increased their authority over almost all sectors of government. Local governments also received a substantial share of the natural resource royalties originating from their district, with some fraction of royalties going to the producing district, some fraction being shared equally among all other districts in the same province, and the rest remaining with Jakarta. Districts were administered by Bupatis (district heads), who were in turn indirectly selected by local legislatures.

The allure of self-government where districts could enjoy significant new political and fiscal powers, as well as a high fixed fee, low per-capita fee structure in the block grant formulas, led to a significant amount of district splitting. The total number of districts increased from 292 in 1998 to 483 in 2008. In the area and time that is the focus of this study (the forest islands of Sumatra, Kalimantan, Sulawesi, and Papua from 2000 to 2008), the total number of districts increased from 189 in 2000 to 312 in 2008. In contrast, the number of districts in Indonesia had remained 
largely unchanged during the 32-year Suharto regime. District splits thus represented a significant mechanism for the further decentralization of power in the country (Fitrani, Hofman, and Kaiser 2005).

\section{III.B. Implications for the Forest Sector}

During the Suharto regime, the 1967 Basic Forestry Law gave the national government the exclusive right of forest exploitation in the so-called Forest Estate (Kawasan Hutan); an area of 143 million hectares equivalent to three-quarters of the nation's territory (ROI 1967; Barber 1990). This is a substantial amount of forest: by comparison, it is roughly equivalent to the U.S. states of California, Montana, and Texas put together, and is roughly double the size of the U.S. National Forest system.

The entire Forest Estate was managed by the central Ministry of Forestry in Jakarta. The ministry in turn awarded a small group of forestry conglomerates (with close links to the regime's senior leadership) most of the timber extraction concessions in the Forest Estate, amounting to an area of about 69 million hectares inside the area designated as Production Forest. These exploitation rights were nontransferable, were issued for up to 30 years, and required the logging companies to manage the forest sustainably through selective logging. The second category inside the Forest Estate was the Conversion Forest, in which the largest wood producers could use Wood Utilization Permits (Izin Pemanfaatan Kayu or IPK) to clear-cut the forest and set up plantations for industrial timber, oil palm, or other estate crops. Logging was prohibited in the remaining zones of the Forest Estate, which were designated for watershed protection (the Protection Forest) and biodiversity protection (the Conservation Forest).

The control over these forest zones changed with the passing of the Regional Autonomy Laws in 1999. The primary change was that the district forest departments became part of the district government, answerable to the head of the district (the bupati), rather than a division of the central Ministry of Forestry.

The district forest office is the main point of control over much of the forest estate, both in terms of authorizing and monitoring legal logging and in terms of controlling illegal logging. For legal logging, the precise role of the district forest office varies depending on the forest zone. For Production Forest, for example, 
the district forest office works with concession holders to develop, monitor, and enforce annual cutting plans. ${ }^{5}$ For Conversion Forest, the district government initiates proposals to the central government that land be converted from forest to other uses, such as oil palm, and is responsible for ensuring that conversion is carried out in the designated areas only.

Given their central role in enforcing forest policy, the district forest office is the key gatekeeper for illegal logging in these zones. For example, a district forest office employee is supposed to be stationed at the gate of every concession to monitor all logs leaving the concession, and at the entrance of all saw mills to check all logs entering the saw mills. All legally felled logs require a transport permit from the district forest office, which is not only checked at sawmills and export points but also verified at regular road checkpoints and at occasional roadblocks. Extracting more than the legal quota from a concession, transporting it, or bringing illegally sourced logs into a mill therefore requires the complicity of the district forest office. The district forest office is also supposed to conduct regular spot-checks in the forest to ensure that the trees that were felled match those specified in the annual cutting plan and that no additional trees are felled.

District forest officials also play a key role in controlling deforestation in the Protection and Conservation areas. For Protection Forest, the district forest office has the responsibility to patrol and ensure that no illegal logging is taking place. Conservation Forest-much of which is national parks-is the only part of the forest estate legally still under central control. However, since the district forest office enforces the processing of logs at sawmills and monitors transportation of logs, logging in those zones also requires the de facto acquiescence of the district forest office.

Anecdotal evidence confirms that district governments play an important role in facilitating illegal logging in a variety of ways. For example, district heads have been found to allow logging to take place outside official concessions (Barr et al. 2006), to

5. In particular, each year the concession holder, working with the district forest office, proposes an annual cutting plan (recana kerja tebang), based on a survey they conduct in coordination with the district forest office to determine how much can be sustainably cut. The district government then negotiates the cutting plan with the national Forest Ministry, which coordinates all of the annual cutting plans nationwide to ensure that they do not exceed the total national annual allowable cut. 
facilitate the creation of new oil palm plantations inside national forest areas, and to sanction the transport and processing of illegally harvested logs (Casson 2001). District officials also have been known to issue conversion permits to clear-cut forest and plant oil palm on their own, even though they do not have the legal authority to do so. Estimates suggest that illegal logging makes up as much as $60 \%$ to $80 \%$ of total logging in Indonesia, making illegal logging a roughly US $\$ 1$ billion a year market, suggesting that these forces play a substantial role in determining the total amount of deforestation (CIFOR 2004).

\section{III.C. Constructing the Satellite Data Set}

Given the prevalence of illegal logging, it is crucial to develop a measure of deforestation that encompasses both legal and illegal logging. To do so, we use data from the MODIS sensor to construct an annual measure of forest change for each year from 2001-2008. The resulting data set traces, at a spatial resolution of 250 meters by 250 meters, the patterns of forest clearing across the entire country over time. This section describes how the forest change data set is constructed from the raw satellite images.

There are two main challenges in constructing satellitebased images of deforestation. First, humid tropical regions like Indonesia have persistent cloud cover that shrouds the region year-round. This makes it difficult to use high-spatial resolution sensors, like Landsat, which have been used to measure annual forest cover change in less cloudy environments. Since these satellites typically only revisit the same area once every 1-2 weeks, cloud-free images are less frequently recorded in Indonesia. An alternative to this is to draw on moderate spatial resolution sensors, such as MODIS, that pass over the same spot every 1-2 days. This considerably increases the likelihood of obtaining cloud-free observations, but at a coarser spatial resolution of 250 meters by 250 meters instead of the 30 meter by 30 meter spatial resolution available via Landsat.

To generate the data used in this article, MODIS 32-day composites are used as inputs and include data from the MODIS land bands (blue [459-479 nm], green [545-565 nm], red [620-670 $\mathrm{nm}$ ], near-infrared [841-876 nm], and mid-infrared [1230-1250, 1628-1652, 2105-2155 nm]) (Vermote, El Saleous, and Justice 2002), as well as data from the MODIS land surface temperature product (Wan et al. 2002). Composite imagery represents the best 
land observation over the compositing period, in this case 32 days. To produce a more generalized annual feature space that enabled the extension of spectral signatures to regional and interannual scales, the 32-day composites are transformed to multitemporal annual metrics. Annual metrics capture the salient features of vegetation growth and senescence without reference to specific time of year and have been shown to perform as well or better than time-sequential composites in mapping large areas (Hansen et al. 2003).

For each annual interval, a total of 438 image inputs is used (146 metrics per year plus their calculated differences) (Hansen et al. 2005). This amount of information, in effect 438 dimensions for each 250 meter by 250 meter pixel, is used to estimate forest cover loss per year for that pixel. By contrast, the human eye, with its three types of cones, measures only three bands, which correspond roughly to the blue, green, and red areas of the visual spectrum. The MODIS-derived data set is thus considerably richer than just a series of visual images at comparable resolution. The next step is to take the composited MODIS inputs and implement a computer algorithm to discriminate between forest and nonforest. The key idea of remote sensing is developing an algorithm that identifies what spectral signatures or set of signatures-that is, what combinations of MODIS-derived spectral and temporal information-best discriminate forest cover and its loss. For example, plants absorb electromagnetic radiation in the visual red part of the electromagnetic spectrum, but reflect or scatter radiation in the near-infrared part. One common metric for measuring vegetation productivity is the NDVI (normalized difference vegetation index), which captures the difference in reflectance of the near-infrared and red parts of the electromagnetic spectrum, and is a useful spectral signature for indicating the presence or absence of vegetation (Tucker 1979). Foster and Rosenzweig's pioneering work relating forest cover to economic factors in India, for example, used satellite-based NDVI measures to detect forest change (Foster and Rosenzweig 2003). ${ }^{6}$

In practice, one can do much better than just using NDVI by exploiting additional dimensions of the data. For example, forests tend to be cooler than surrounding areas, so bands that measure

6. See also Morjaria (2012) who examines the link between electoral competition and deforestation in Kenya using Landsat satellite data. 
temperature can also be used. Moreover, trees have different spectral signatures than other types of crops and plants (Jensen 1995). To take maximal advantage of the richness of the MODIS data, we use a statistical learning procedure known as a decision tree bagging algorithm to determine which spectral signatures best correspond to forest (Breiman 1996).

Specifically, we start with much higher resolution training images. For each of these images (consisting of the best available Landsat data), experts classify each pixel as having experienced forest cover loss (clearing) or not. We then relate these labels to corresponding MODIS data using the decision tree algorithm. The decision tree algorithm is a nonlinear, hierarchical tool for recursively partitioning a data set into less and less varying subsets regarding the variable of interest, in this case forest cover loss. The method makes no assumptions on the distribution of the data in spectral space, allowing for the robust and precise division of the spectral data into estimates of forest cover loss using a series of nested partitioning rules. One then extrapolates the derived rule set over the entire MODIS data set to predict, for each year, a per pixel probability of forest cover loss. We code a pixel as cleared if the estimated probability of deforestation exceeds $90 \%$.

The final outputs are annual forest change estimates for 2001-2008 for each of the 34.6 million pixels that make up Indonesia. Note that these estimates will provide a lower bound for forest change, as a 250 meter by 250 meter pixel is only coded as deforested if the majority of the area represented by the pixel is felled. This will reliably pick up clear-cutting, but will not necessarily capture selective logging if the forest canopy remains largely intact, and therefore will underestimate total logging. Identified change is to be treated as an indicator of likely forest change. The measure will also capture deforestation due to large-scale burns, which can be either intentional (for land clearing purposes, usually after logging of valuable trees has already taken place) or unintentional.

This cell-level data is then summed by district and forest zone (i.e., the four forest categories in the Forest Estate: the Production, Conversion, Protection, and Conservation Forest). This yields our final left-hand-side variable deforest $_{d z t}$, which counts the number of cells likely to have been deforested in district $d$ in forest zone $z$ and year $t$. 
Figure I gives an idea of what our underlying forest cover data looks like. To do this we zoom in onto a small area, since the detailed nature of this data set makes it impossible to visualize the 34.6 million pixels that make up Indonesia on a single map. It focuses on one of the main hotspots of deforestation during this time period (Hansen et al. 2009), namely, the province of Riau on the island of Sumatra. The deforested cells are indicated in red, forest cover is shown in green, and nonforest cover in yellow. The map clearly shows that substantial amounts of forest have been deforested during the period from 2001 to 2008. Furthermore, forest clearing seems to spread out from initial areas of logging, as access will be easier from already logged plots.

In addition to the satellite data, to obtain data on prices we also examine logging statistics from the annual Statistics of Forest and Concession Estate (Statistik Perusahaan Hak Pengusahaan Hutan), published by the Indonesian Central Bureau of Statistics for 1994-2007. These statistics report the quantity and value of logs cut at the province level and the associated price by wood type, for 114 different types of wood. ${ }^{7}$ Because they are derived from production, they include both clear felling as well as selective logging; on the other hand, they capture only logging that was officially reported by the forest concessions, and so likely miss most illegal logging. Since they report the wood cut from the Production Forest, they should be compared to the satellite data from the Production zone. We divide value by quantity to obtain data on the price of wood; since market prices are determined by both legal and illegal logging, these prices will reflect the market equilibrium for both types. We use this second data set as a consistency check for our satellite data and to examine impacts on prices, as described in further detail in Section IV.

\section{III.D. Descriptive Statistics of Forest Change}

Figure II illustrates the distribution of pixels coded as likely deforested at the district level across Indonesia over time. In particular, it shows the number of cells coded as likely deforested at the district level in 2001 and 2008. We focus our analysis on the main forest islands of Indonesia: moving from west to east, these are Sumatra, Kalimantan, Sulawesi, and Papua. The remaining

7. We drop the other (lainnya) and mixed wood (rimba campuran) category, since their composition varies considerably across provinces and over time. 


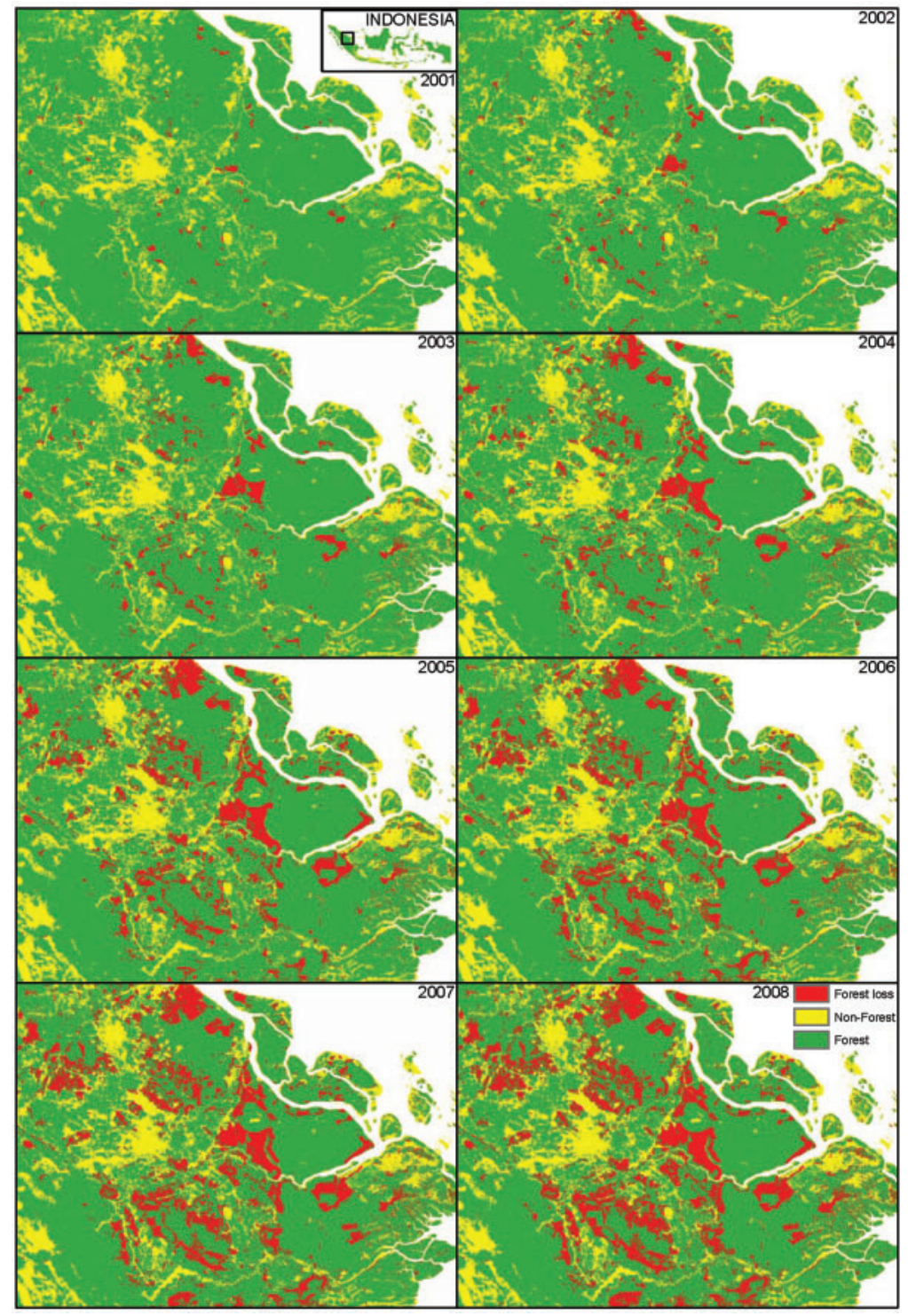

O
0
0
0
0
0
0
0
0
0
0
0
0
0
0
0
0
0
0
0
0
0
0
0
00
0
0
0
0
0
0
0
0
0
0
0
0
0
0
0
0
0
$z$
0
0
0
0
0
0
0
0
$N$
0

FiguRe I

Forest Cover Change in the Province of Riau, 2001-2008 

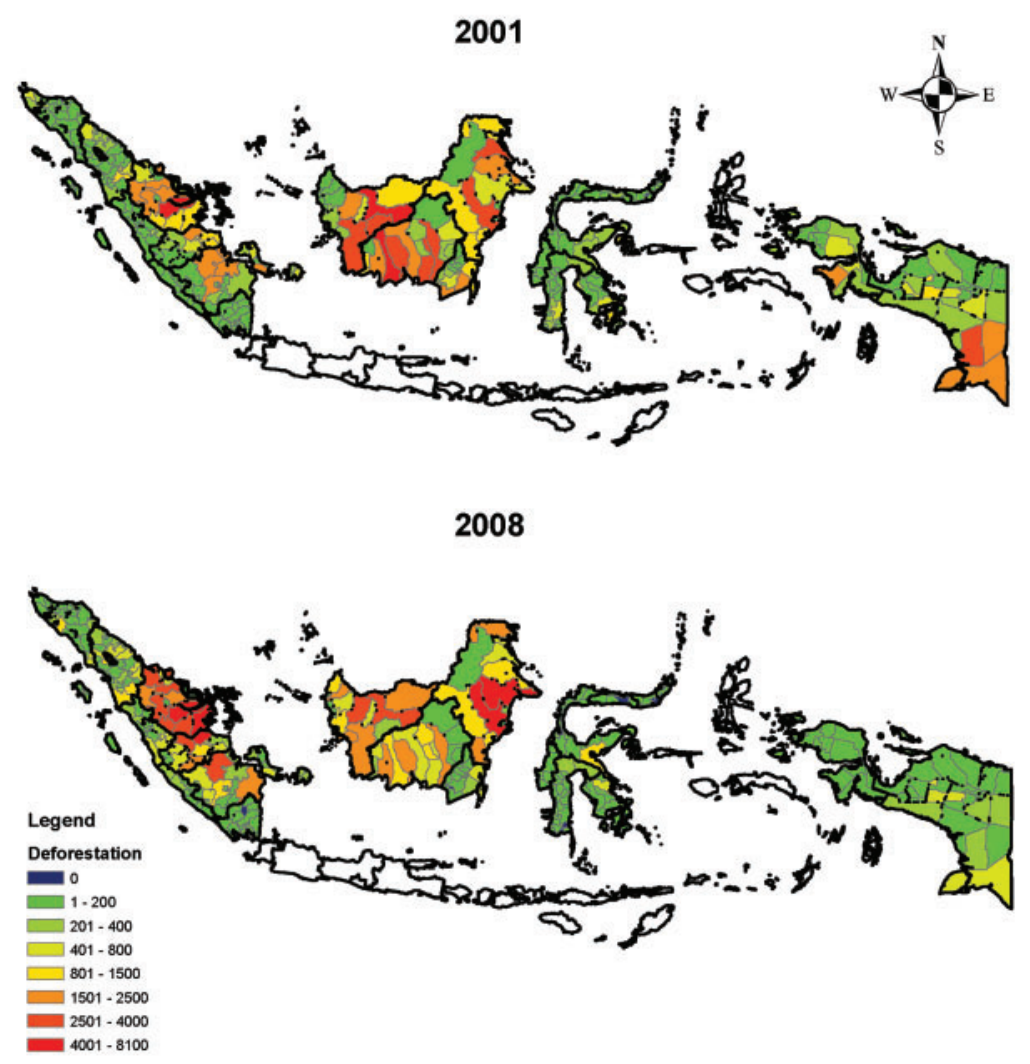

FiguRe II

District-Level Logging in Indonesia Using the 2008 District Boundaries, 2001 and 2008

islands (Java, Bali, NTB/NTT, Maluku, and the Riau Islands near Singapore), shown in white, have negligible forest cover in the baseline period and are not included in our sample. In this map, low levels of likely deforestation are shaded in green, whereas high levels of likely deforestation are indicated in orange and red. The figures suggest that most of the deforestation occurs in Kalimantan and in the lowlands of Sumatra along its eastern coast. From 2001 to 2008, there is a shift in deforestation in Kalimantan from the west to the east, and there is an 
intensification in deforestation in Sumatra, particularly in the provinces of Riau and Jambi in the east-center of the island.

Table I reports the trends in forest cover over time in more detail, and Table II displays the summary statistics for our main measure of deforestation. The data in both tables are reported for the entire Forest Estate, the subcategories of the Forest Estate where logging may be legal (Production/Conversion Forest) and where all logging is illegal (Conservation/Protection Forest), as well as the individual subcategories of the Forest Estate. Table I shows the changes in the forest area measured in MODIS pixels (each of which represents an area approximately 250 meters by 250 meters). Total deforestation (by the measure constructed here) between 2000 and 2008 amounts to 783,040 pixels. Although MODIS pixel change does not detect all forest change (as some forest change occurs below the level detectable by MODIS [Hansen et al. 2009]), it is worth noting that 783,040 pixels represents 48,940 square kilometers; this is roughly twice the size of Vermont.

Most of this change occurs in the Production Forest, where 487,000 pixels (representing an area of 4.2 million hectares) were coded as likely deforested. Much smaller changes are reported for the other forest zones: 179,000 pixels were deforested in the Conversion Forest and only 117,000 pixels were deforested in the Conservation and Protection Forest combined. To the extent logging is selective, moderate resolution sensors like MODIS will underestimate these changes.

Table II shows the summary statistics of our main lefthand-side variable, deforest ${ }_{d z t}$, which counts the number of cells likely deforested for district $d$ in forest zone $z$ and year $t$. On average, 113 pixels (the equivalent of 704 hectares) are deforested annually at the district level. However, the variance of 464 pixels (four times the mean) suggests that there is substantial variability in deforestation both across years and districts. The pattern of the results mimics the previous findings, that is, most of the changes occur in the Production Forest, where on average 232 pixels (representing 1,451 hectares) are coded as likely deforested in each district and year.

\section{III.E. Political Economy Data}

To capture increasing competition in the wood market, we take advantage of the extensive partitioning of districts following 


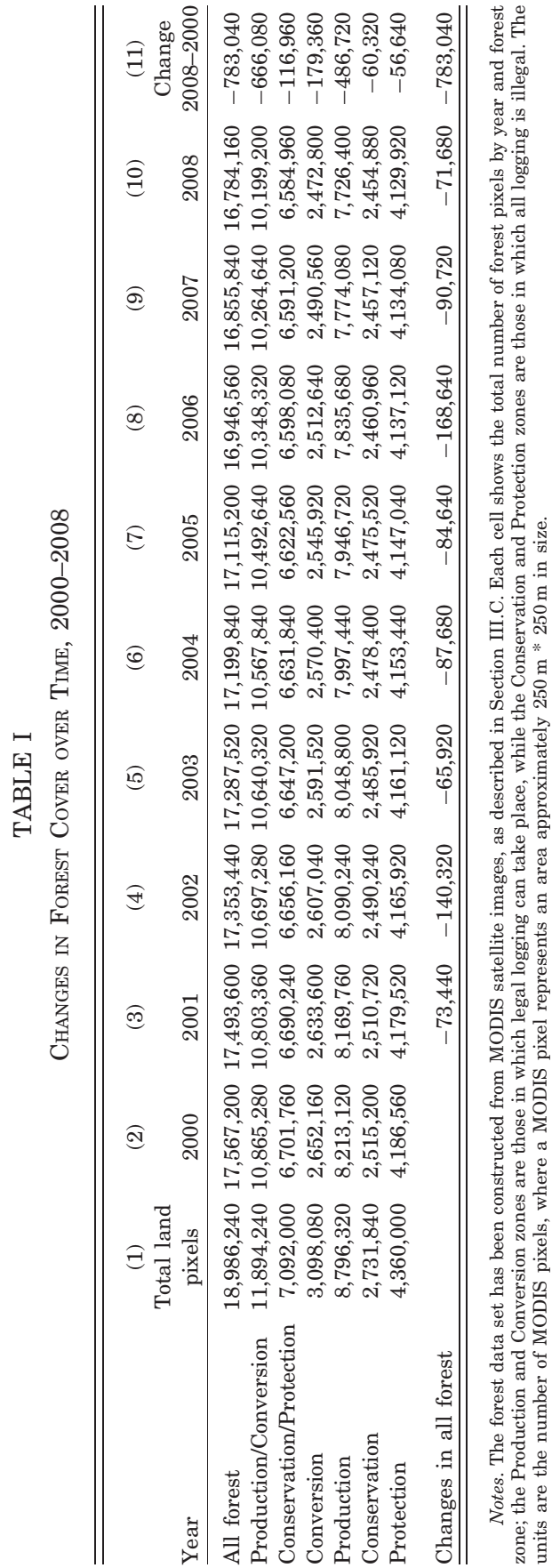




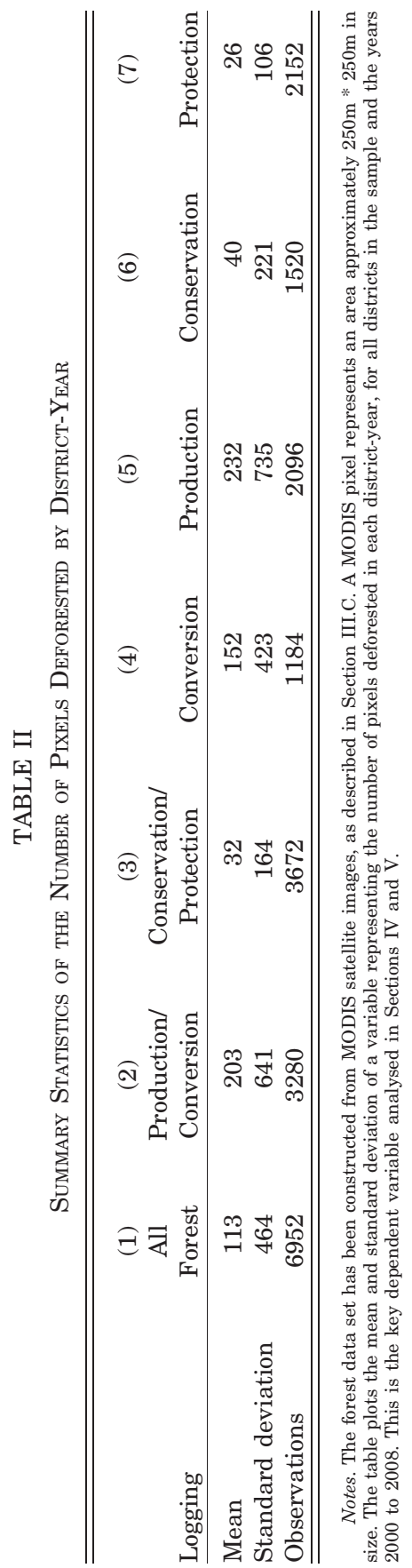




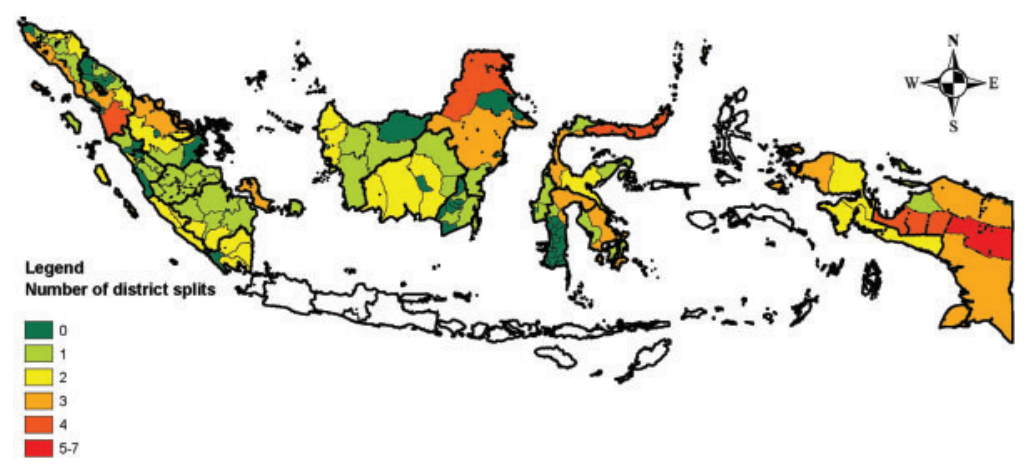

Figure III

Total Number of District Splits Using the 1990 District Boundaries

the collapse of the New Order regime. Figure III illustrates the distribution of district splits in our forest island sample. It displays the total number of districts that the original 1990 district was partitioned into by 2008 . The map shows that district splits happen all over the country, and very few of the 1990 districts remain intact.

At the province level, Table III shows the number of new districts established in each province in each year for the forest-island provinces in our sample. Table III shows that every province in our sample had at least one new district established during our period. Most provinces had some new districts established in both the early period (2001-2003) and the late period (2007-2008) - 19 out of 21 provinces have at least one new district created between 2001 and 2003, and 16 out of 19 provinces have at least one new district created in 2007 or 2008. The national moratorium on the establishment of new districts from 2004-2006 appears to have been followed in all provinces. The variation that we exploit when exploring the implication of district proliferation on deforestation is thus primarily on the intensive margin (the number of new districts created, rather than whether a district is created) and the differential timing of the creation of these new districts.

We use the official date that the national parliament approved the formation of a new district to code the number of districts present at a given area at $t$. For the province-level data, 
we calculate the total number of districts and municipalities in province $p$ on island $i$ in year $t$, NumDistrictsInProv ${ }_{p i t}$.

To examine the impact of other sources of rents available to district governments, we examine oil and gas revenues per capita at the district level, PCOilandGas $d t .{ }^{9}$ Oil and gas revenue is shared among districts according to a formula stipulated in a national law, which states that $15 \%$ of state revenues from oil and $30 \%$ of state revenues from natural gas are distributed to the regions, with the rest going to the center. For the revenue going to the regions, half goes to the producing district and the remaining amount is divided equally among all districts in the province. ${ }^{10}$ We obtain the revenue data from the Indonesian Ministry of Finance web page (http://www.djpk.depkeu.go.id/ datadjpk/57/) and the population data for 2008 from the Indonesian Central Bureau of Statistics. It is important to note that new districts often do not record their own share of revenue for the first few years after the split, as the district is not yet fully functioning. We therefore allocate each new district the revenue share of its originating district until it reports its revenue for the first time.

Figure IV displays oil and gas revenue per capita in 2008 at the district level. These natural resources are much more spatially concentrated than forest, so that most districts receive very little or no revenue shown as blue and green respectively. The districts that receive the largest share of revenue from oil

8. Each province is located on only one of the four islands-Sumatra, Kalimantan, Sulawesi, and Papua. We use the island subscript, $i$, as we will allow for differential time trends by island in the empirical analysis below.

9. Oil and gas is by far the largest source of natural resource rents for districts. For instance, in 2008 the average district-level revenue from oil and gas was 114.5 billion rupiah, whereas the corresponding figure for forestry was 5.3 billion rupiah. On average, oil and gas revenue sharing corresponds to about $1 \%$ of district GDP for the districts in our sample; for nonproducing districts, the figure is about $0.5 \%$. While fluctuations in oil and gas revenue sharing from year to year are therefore large as a share of government revenues, they are not enormous compared with district GDP, particularly for nonproducing areas.

10. To be specific, suppose that there are $N_{p}$ districts in province $p$. Each district $d$ produces oil revenues $o_{d}$ and natural gas revenues $g_{d}$. Each district's revenue sharing is thus equal to

$$
R_{d p}=0.075 o_{d p}+0.15 g_{d p}+\frac{0.075}{N_{p}-1} \sum_{j \neq i} o_{j p}+\frac{0.15}{N_{p}-1} \sum_{j \neq i} g_{j p} .
$$




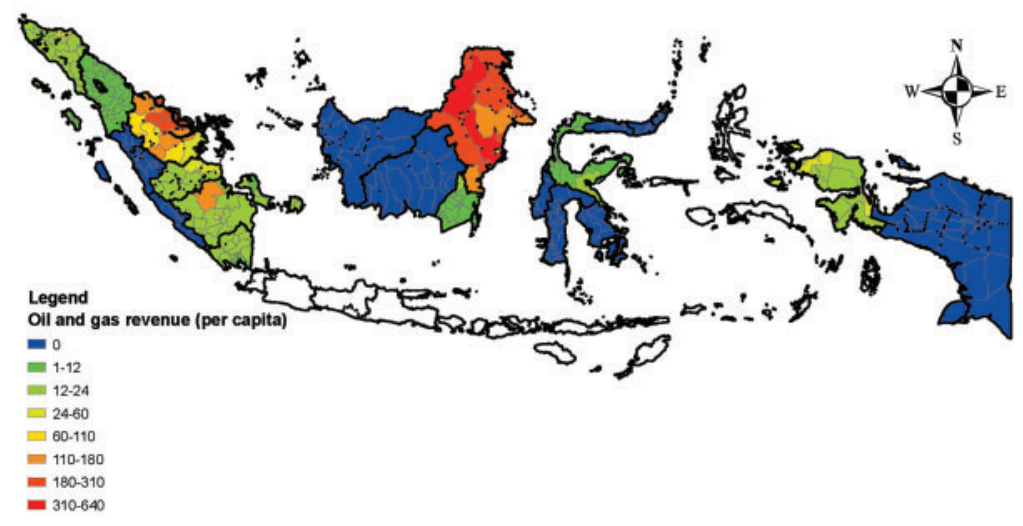

Figure IV

Oil and Gas Revenue per Capita Using the 2008 District Boundaries, 2008

and gas extraction are located in Eastern Kalimantan and in the province of Riau on Sumatra. The map shows that there is some heterogeneity across districts within each province, where provinces are delineated with thick black borders. These differences are due to the revenue sharing rule, which implies that oil and gas producing districts in a province receive substantially more than non-producing districts.

\section{INCREASES IN POLITICAL JURISDICTIONS}

In this section, we consider the implications of subdividing political jurisdictions for deforestation. As discussed, across all of Indonesia, the number of districts increased from 292 prior to decentralization to 483 in 2008; in the forest islands that are the focus of this study, it increased from 146 districts prior to decentralization to 312 districts in 2008, an increase of $113 \%$. We exploit the staggered timing of these changes (see Table III) to identify the relationship between the number of administrative units and deforestation.

Our theoretical framework predicts that the quantity of forest removed should increase and that wood prices should decline as the number of political jurisdictions increases. We will 
test these predictions empirically, consider whether the magnitudes appear consistent with what one would expect from a Cournot model, and examine several alternative explanations for the results.

\section{IV.A. Empirical Specifications}

We examine how deforestation responds when a district is subdivided to create new administrative jurisdictions. As analyzed in detail in Fitrani, Hofman, and Kaiser (2005), the splitting of districts was driven by three principal factors: geographic area, ethnic clustering, and the size of the government sector. ${ }^{11}$ Because all analysis in this article is identified from the timing of the splits, not whether they occur, the key question from the perspective of this article is not whether a district splits but what determines the timing of the split.

Several idiosyncratic factors appear to influence the timing. First, the process of splitting a district is quite cumbersome, involving a number of preliminary steps (e.g., formal agreement of the district legislature, the district head, the provincial governor, and the provincial legislature; documentation of the new districts' ability to meet fiscal requirements; documenting a reason for the split) and, ultimately, the passage of a special law by the national parliament for each split that takes place. The amount of time these steps take varies, which in turn influences the total amount of time. Moreover, as discussed there was a national moratorium on splits from 2004 (when the criteria for splits were revised) through 2007 . This moratorium also creates

11. Specifically, the Suharto-era districts were often quite large, so naturally they find that districts that were larger geographically are more likely to split to make administration easier. Second, there are often ethnic tensions in Indonesia, particularly off Java. Those districts where the different ethnic groups were clustered geographically were more likely to split. Finally, the block grant fiscal transfer (DAU) had a fixed component per district. While this gives all districts an incentive to split, they find that it is particularly likely in those districts with a large wage bill, who presumably are in greater need of the revenue. They find little consistent relationship between natural resources and splitting, with positive coefficients in the 1998-2000 period and negative coefficients in the 2001-2003 period, implying zero effect on average across their sample period. Details of these regressions can be found in Fitrani, Hofman, and Kaiser (2005). Note that although splits do lead to more resources, the evidence presented in Section V suggests that if anything, more government resources leads to less deforestation, not more, so the additional resources from the DAU formula are unlikely to be driving the results here. 
plausibly exogenous delays in timing of splits, as many districts that may have been close to completing the process in 2004 had their split postponed by three years due to the moratorium (though we do not observe which district splits were in progress when the moratorium was imposed). In the empirical analysis we show that the timing of these splits is not associated with pretrends in deforestation, though a priori there is little reason to believe they would be. In Online Appendix Table A.1, we also show that the year a district split is uncorrelated with factors such as population, area, oil and gas revenues, share of land that is forested, or the pre-period rate of deforestation. We also show that neither district corruption (as measured by the share of missing rice from a public distribution program; see Olken 2006) nor the vote share of the former party of Suharto (Golkar) is correlated with the year when a district splits.

To test the Cournot theory, a key question is how to define the "market" for wood products. While wood and wood products are traded on international markets, several factors make wood markets in Indonesia more local. In particular, since 2001 Indonesia has banned the export of raw logs. Instead, all timber felled in Indonesia must first be transported (either by river, when possible, or by road) to local saw mills, plywood mills, and paper mills, where it is processed before export. These factors imply that prices may differ across regions. We focus on the province as the key definition of a market, because provincial boundaries are coincident with the major river watersheds used for transporting logs by water. Province boundaries are also coincident with mountain ranges which make transporting logs across provinces by road generally more difficult than transporting logs by road within provinces. Provincial boundaries are also the smallest level at which our price data are available.

We examine several empirical predictions of the Cournot theory. First, taking a province as a measure of the market, we use panel data to test whether the number of districts in the province affects the quantities and prices of wood felled in the province. For our primary measure of deforestation, we use the MODIS satellite-based data, which captures both legal and illegal deforestation. To examine the impact on prices, we examine the official forestry statistics.

For the satellite-based forestry data, since our key dependent variable is a count - that is, how many pixels were deforested in a given year-we will run a fixed-effects Poisson quasi-maximum 
likelihood (QML) count model (Wooldridge 1999), with robust standard errors clustered by province to account for arbitrary serial correlation over time within provinces. Specifically, we estimate, by MLE, equations such that

$$
\mathbf{E}\left(\text { deforest }_{p i t}\right)=\mu_{p i} \exp \left(\beta N u m D i s t r i c t s I n \text { Prov }_{p i t}+\eta_{i t}\right),
$$

where deforest $t_{\text {pit }}$ is the number of pixels deforested in province $p$ (located on island $i$ ) in year $t$, NumDistrictsInProv $_{\text {pit }}$ counts the total number of districts in province $p$ in year $t, \mu_{p i}$ is a province fixed effect, and $\eta_{i t}$ is an island $\times$ year fixed effect. Including island $\times$ year fixed effects allows for flexible time trends in deforestation across different parts of the country over time. ${ }^{12}$ The coefficient $\beta$ in Equation (5) represents the semi-elasticity of deforestation with respect to the number of districts in the province. The reason we use the Poisson QML count specification for the satellite data, rather than estimate a log dependent variable with ordinary least squares (OLS), is that we have observations where the dependent variable is 0 , so a count model is more appropriate. The Poisson QML count model in (5) is robust to arbitrary distributional assumptions, so long as the conditional mean is specified by (5). The robust standard errors are clustered at province boundaries. ${ }^{13}$ We estimate this equation separately by land-use zones.

12. As shown in Table III, the four island groups are Sumatra, Kalimantan, Sulawesi, and Papua. Including separate island time trends is important because the different island groups are indeed on different trends (deforestation is increasing slightly in Sumatra, decreasing slightly in Kalimantan, and decreasing more substantially in the eastern islands of Sulawesi and Papua). The differential trends are likely driven by a shift in the composition of logging nationally towards supplying the large pulp and paper mills located in Sumatra. Online Appendix Table A.6 shows that the results are robust to dropping islands one by one, so that no particular island is driving the results. The results also appear roughly similar (although imprecise) if they are estimated island by island.

13. Note that province borders changed over our sample period. In 1990 (i.e., under Suharto), there were 17 provinces in our sample area; in 2001, at the start of our data, there were 19 provinces in our sample area, and in 2008, at the end of our data, there were 21 provinces in our sample area. Districts are not split across province lines. Since the finer provinces correspond more naturally to geographic units (e.g., West Sulawesi; West Papua), in our main specifications we use the finer 21-province definitions for the analysis, but cluster standard errors at the original 17-province level. If we use the 17-province level 1990-era borders for the analysis instead, the estimates with no lags attenuate, but the estimates with lags remain virtually unchanged. See Online Appendix Table A.20. 
For the price (and quantity) data from the official production statistics, we run an analogous OLS fixed effects regression, as follows:

$$
\log \left(y_{\text {wpit }}\right)=\beta \text { NumDistrictsInProv }{ }_{\text {pit }}+\mu_{\text {wpi }}+\eta_{\text {wit }}+\varepsilon_{\text {wpit }},
$$

where $y_{\text {wit }}$ is the price or the quantity of wood type $w$ harvested in province $p$ and year $t$. The regression also controls for wood-type-by-province and wood-type-by-island-by-year fixed effects, $\mu_{w p i}$ and $\eta_{w i t}$, respectively. Since there is substantial variation in quantity of wood across wood species and provinces- the 5 th percentile of the quantity variable is $42 \mathrm{~m}^{3}$, whereas the 95 th percentile of the quantity variable is $204,804 \mathrm{~m}^{3}$-this regression is weighted by the volume of production of wood type $w$ in province $p$ in the first year that we have data, so the coefficient is approximately interpretable as the effect on average prices in the province. Note that if one takes logs of Equation (5), the coefficient $\beta$ in Equation (5) is directly comparable to the coefficient $\beta$ in Equation (6); both represent the semi-elasticity of deforestation with respect to the number of districts in the province. ${ }^{14}$

\section{IV.B. Impacts on Quantities}

1. Main Results. Table IV begins by estimating Equation (5). The table reports the findings separately for each subcategory of the Forest Estate. Column (1) presents all categories of the Forest Estate pooled together, column (2) presents results for the zones where legal logging can take place (i.e., the Production and Conversion zones), and column (3) presents results for the zones where no legal logging can take place (i.e., the Conservation and Protection zones). ${ }^{15}$ The remaining four columns show the results for each individual zone.

The total estimated impact of district splits on deforestation is shown in column (1) of Panel A. We find that the annual rate of deforestation increases by $3.85 \%$ if an additional district is formed within a province.

14. The only difference is that Equation (6) is weighted by initial volumes in production (deforest ${ }_{w p 0}$ ), whereas the Poisson model implicity uses contemporaneous volumes for weights (deforest $t_{w p t}$ ) (see VerHoef and Boveng 2007). We show in Online Appendix Table A.10 that using contemporaneous weights when estimating Equation (6) produces virtually identical results.

15. As discussed, since the Poisson model weights each observation by the quantity, when we combine observations from multiple zones we obtain the correct weighted average effect. 
Looking across the various zones of the Forest Estate, the point estimates suggest broadly similar impacts on extraction in the zones where logging could be legal or illegal (Production: $5.35 \%$, statistically significant at $1 \%$; Conversion: $3.87 \%$, not statistically significant) and in one of the zones where deforestation is clearly illegal (Conservation: $9.76 \%$, statistically significant at $5 \%$ ). This suggests that the impact of the increasing number of political jurisdictions is not merely being driven by changes in the allocation of legal cutting rights, but that something is happening with regard to illegal logging as well, as would be predicted by our theoretical framework.

Panel B reports the estimates of the medium-run impact of district splits by including three lags of the NumDistrictsInProv ${ }_{\text {pit }}$ variable. We focus on the sum of the immediate effect and the first three lags, which is the net impact of adding an additional district to the province three full years later. ${ }^{16}$ In virtually all cases, the medium-run impact estimated by calculating the sum of the immediate effect and all three lags is even larger than in the main specification. For example, three years after the split, a district split increases deforestation in the entire Forest Estate by $8.22 \%$. The estimates for deforestation in legal and illegal logging zones, reported in columns (2) and (3), respectively, are now both significant and of similar magnitude$8.09 \%$ on average for the Production and Conversion zones (where logging could be legal or illegal) and $10.1 \%$ for the Conservation and Protection zones (where all logging is illegal). The fact that the cumulative effect on logging three years after the split is even larger than the immediate impact, especially in the zones where all logging is illegal, suggests that the impact is not merely being driven by declines in enforcement associated with new district creation.

16. Since the NumDistrictsInProv variable is highly serially correlated ( $\rho \approx 0.8$ ), the individual lag coefficients are not particularly well identified. However, the sum of the immediate effect and the first three lags is much better identified, since the NumDistrictsInProv variable is not that highly correlated with its third lag. We therefore report the sum of the immediate effect and the first three lags in the table, and report the full set of results including individual lag coefficients in Online Appendix Table A.2. The results do not change substantially if we use five lags instead of three. 
2. Robustness and Additional Specifications. An important potential concern is that the timing of splits is correlated with existing trends in logging. To investigate this, Online Appendix Table A.4 repeats the baseline specification from column (1) of Table IV, but adds various types of trends. Online Appendix Table A.4 shows that the results are virtually unchanged if we add pre-period provincial per capita expenditure or pre-period provincial forest cover interacted with linear trends. Adding pre-period population interacted with a linear trend, or adding arbitrary province-specific linear trends, reduces the coefficient on number of districts somewhat, so that the estimate is no longer statistically significant with no lags, though the coefficient on the immediate effect and the sum of the three lags remains statistically significant. These results confirm that the results do not appear to be driven by underlying trends correlated with the introduction of new districts.

An alternative approach to checking for pre-trends is to repeat the analysis in Table IV including leads as well as lags. Online Appendix Table A.5 shows that our main results are robust to the inclusion of leads, and that the $p$-value of a joint significance test for the leads is large and statistically insignificant for all zones (ranging from 0.20 to 0.71 , depending on specification), once again suggesting that there are no substantial differential pre-trends. Additional robustness checks show that the results are essentially unchanged by omitting any particular island group (see Online Appendix Table A.6), and that the results are qualitatively similar (though slightly less precise in Panel A) when estimated using OLS with a log dependent variable and different weighting schemes on the nonzero observations instead of the more efficient robust Poisson model that uses all data points, including zeros (see Online Appendix Table A.7). On net, the robustness checks suggest that the results do not appear to be driven by pre-trends and are robust both to changing the sample and to alternate functional forms. ${ }^{17}$

Because the satellite data yield deforestation at a very fine pixel level, we can further disaggregate logging by district as well as by forest zone. This allows us to separately estimate the direct effect of a district splitting - that is, the impact in the district that splits itself-from the indirect effect of the district

17. Online Appendix Table A.9 also shows that the results are robust to excluding cities and do not hold if one restricts the analysis to city districts. 


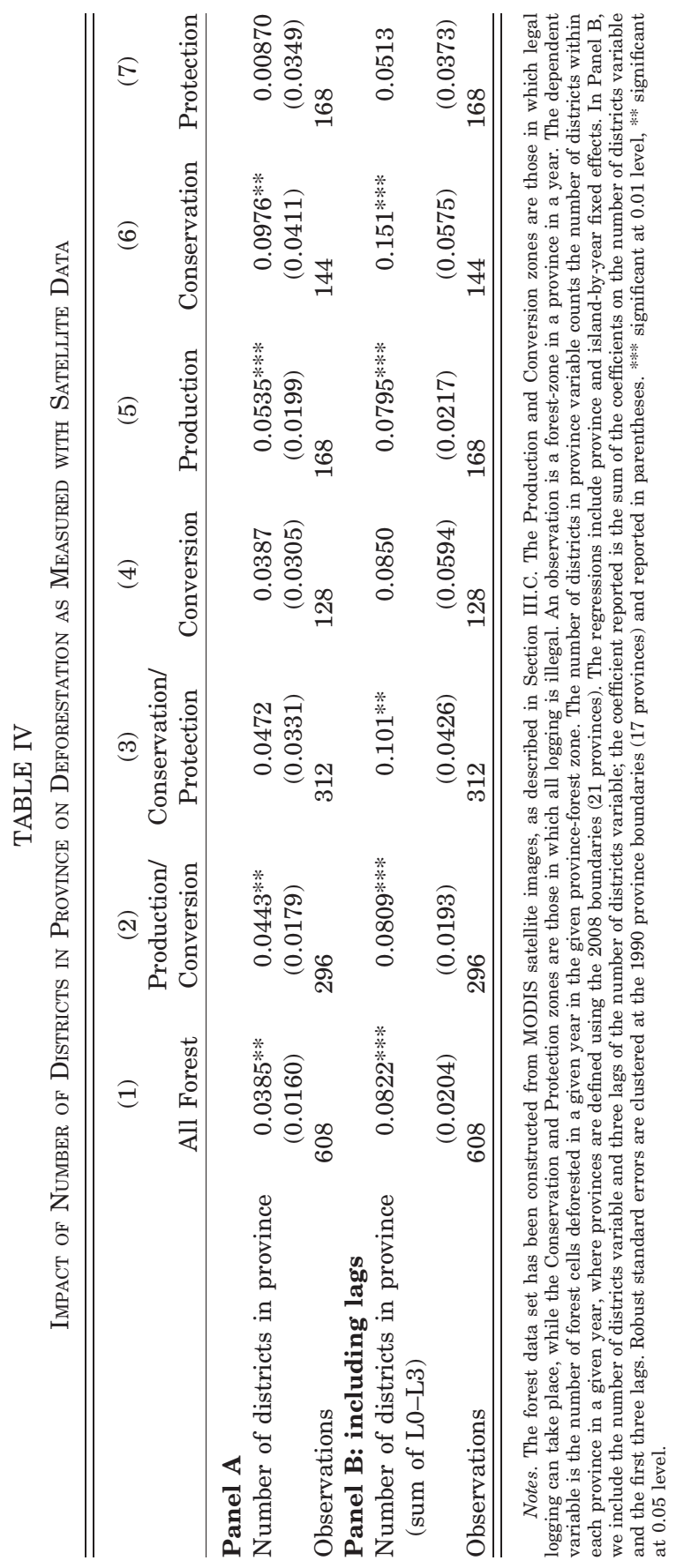


splitting - that is, the impact on logging on other districts in the same province. ${ }^{18}$ The results, shown in Online Appendix Table A. 8 , suggest that while illegal logging in the district that splits increases immediately after the split occurs, there is a temporary disruption in legal logging in the district that splits as the new district government is organized. In response, other districts in the same province respond immediately by increasing deforestation in all zones. Over time, total deforestation appears to increase in the district that splits as well. The spillover effects are consistent with dynamic Cournot effects with a nonrenewable resource as in Lewis and Schmalensee (1980), whereby the other districts increase production immediately in response to the anticipated future increase in logging that will occur once the new district is fully up and running. Online Appendix Table A.12 contains five as opposed to three lags and shows a similar pattern. Additional details of this analysis can be found in the working paper version of the article (Burgess et al. 2011).

\section{IV.C. Impacts on Prices}

If the Cournot theory outlined in Section II is important, we would expect increasing numbers of political jurisdictions not only to increase quantities of deforestation but also to decrease prices. To examine this, we turn to the official production data. These data capture the value and quantity of all logs from the official forest concession reports, separately for each species, province, and year. Logging concessions are all in the Production zone, so they are most comparable to the Production zone estimates from the satellite data. By dividing value by quantity, we can obtain the price the concession obtained for the wood. Although the official production statistics will not capture illegal logging, the prices concessions receive for their legally felled timber should reflect the prevailing market prices in the area,

18. To do this we estimate via Poisson QML a model such that:

$$
\mathbf{E}\left(\text { deforest }_{d i t}\right)=\mu_{d i} \exp \left(\beta N u m O w n \text { istricts }_{d i t}+\gamma \text { NumOtherDistricts }{ }_{d i t}+\eta_{i t}\right),
$$

where deforest $t_{d i t}$ is the number of cells cleared in district $d$ (located on island $i$ )

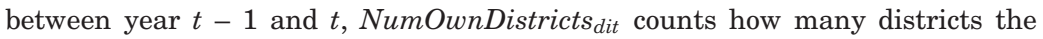
original 1990 district $d$ split into by year $t$, and NumOtherDistricts ${ }_{d i t}$ counts how many other districts there are within the same province in year $t$. It also includes district * forest zone fixed effects $\mu_{d i}$ and island-by-year fixed effects $\eta_{i t}$. An observation is based on the 1990 district boundaries, and the robust standard errors are clustered at the 1990 district boundaries. 
which will be determined by the quantities of both legal and illegal logging.

Table V reports results from estimating Equation (6), using the data on prices and quantities from the official forest concession reports. Columns (1) and (2) provide the estimates for our main specification, which includes all wood types and covers the period 2001-2007. Columns (3) and (4) show the results for the same sample period, but restrict attention to a balanced panel of wood types, where we observe production of the wood type in all years for a given province. Columns (5) and (6) present the results for all wood types for a longer time horizon that also includes the years of the predecentralization period for which the official logging publications were also available, that is, for 1994-2007. Panel A displays the estimates for the contemporaneous effect (i.e., estimating Equation 6 with no lags), and Panel B estimates the medium-run impact by including three lags of the number of districts variable (Panel B shows the sum of the immediate effect and 3 lags; individual coefficients are in Online Appendix Table A.3). Columns (1), (3), and (5) show results where the natural log of prices are the dependent variables, and columns (2), (4), and (6) present results where the natural log of quantities are the dependent variables.

Consistent with the theory, the main results in columns (1) and (2) of Panel A show that adding one additional district in a province decreases prices by $1.7 \%$ and increases the quantity of logs felled by $8.4 \%$, though the impact on prices is not statistically significant. Panel B estimates the medium-run impact of the number of districts on prices and quantities by including three lags of the NumDistrictsInProv pit $_{\text {variable (results using five lags }}$ are similar). The medium-run impact estimated by calculating the sum of the immediate effect and all three lags is even larger than in the main specification, as at the end of three years prices have fallen by $3.4 \%$ and quantities increased by $13.5 \%$, and the impact on prices is now statistically significant at the 5\% level. Similar results are obtained for the alternative samples shown in columns (3)-(6), and the price effect becomes statistically significant in both Panel A and B when we use the entire sample.

Because increasing the number of districts is essentially a supply shock, one can infer the slope of the demand curve from the ratio of $d L n Q u a n t i t y$ to $d L n P r i c e$. Combining the estimates from columns (1) and (2) from Table V implies a demand elasticity of -5.24 . However, since the official production statistics miss 


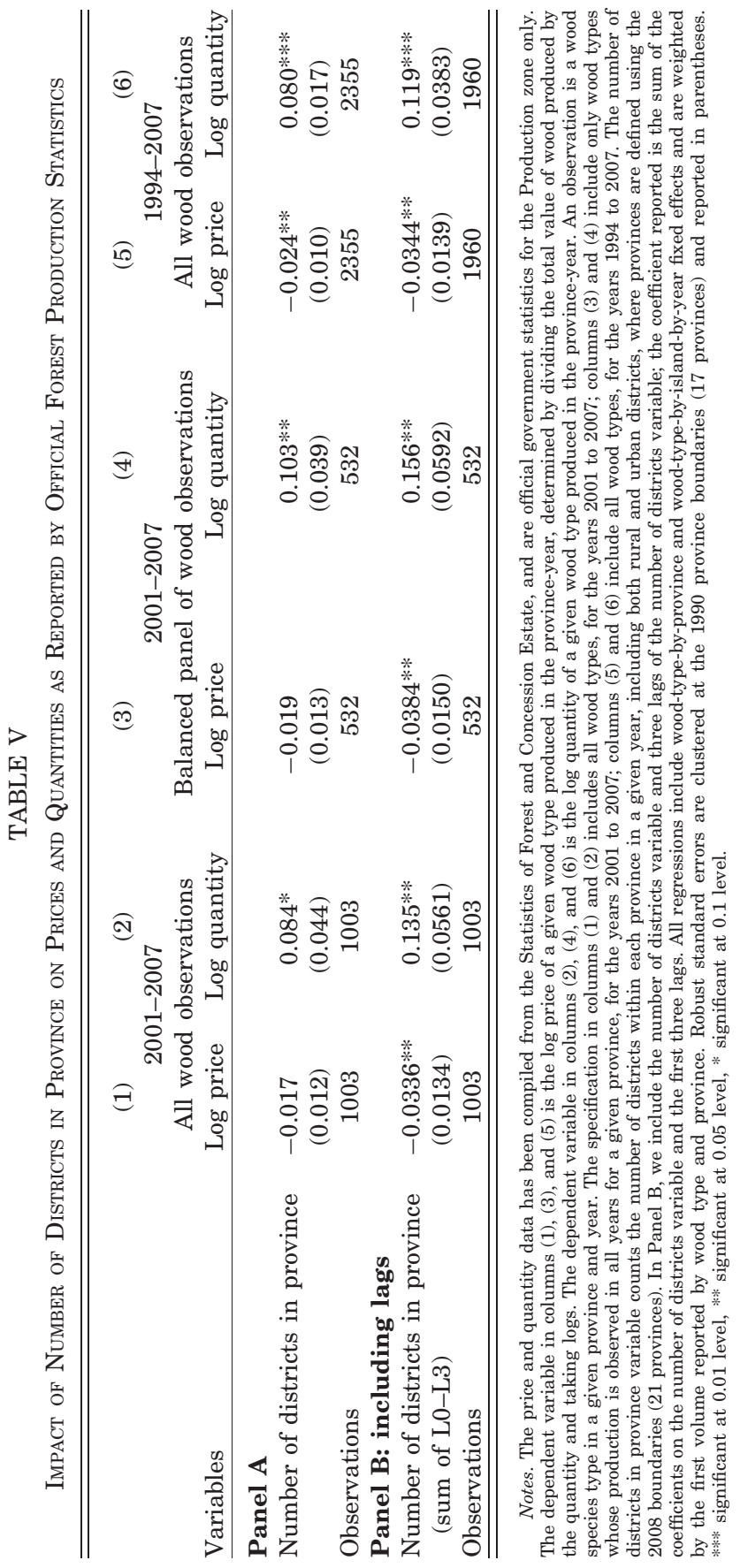

Ð
0
0
0
0
0
0
0
0
0
0
0
0
0
0
0
0
0
0
0
0
0
0
0
0
0
0
0
0
0
0
0
0
0
0
0
0
0
0
0
0
$z$
0
0
0
0
0
0
0
0
$N$
0 
illegal logging, a more reliable estimate of the elasticity can be found by taking the price effects from the official data and the quantity effects from the satellite estimates in Table IV. Using the satellite data estimates in Table IV that adding an additional district increases quantities by $3.85 \%$, we obtain a demand elasticity of -2.27 . Alternatively, using the medium-run estimatesthe increase in quantities of $8.22 \%$ from Panel B of Table IV and the increase in prices of $3.4 \%$ from Panel B of Table V-we obtain an estimated medium-run elasticity of -2.41 -almost exactly the same as the short-run elasticity estimate of -2.27 . Given that the downward-sloping demand curve within a province is determined by transportation costs across provincial boundaries, we would expect that demand for forest products should be reasonably elastic, consistent with the high elasticities we find in the data.

We have also verified that these results are robust to a variety of alternate specifications. We have excluded cities, used contemporaneous weights, and repeated the analysis of leads of district splits for the official data in Online Appendix Table A. 10. We have repeated the analysis where we include various types of linear trends (population, per-capita expenditure, and pre-period forest, all interacted with linear trends, as well as arbitrary linear trends) in Online Appendix Table A.11. The results show broadly similar results across all specifications.

\section{IV.D. Interpreting Magnitudes in a Cournot Framework}

The empirical analysis showed that as the number of jurisdictions increases, the quantity of deforestation in that province increases and the price of wood falls, as one would expect from a model of Cournot competition. Specifically, focussing on the satellite data (which captures both legal and illegal extraction), the overall semi-elasticity of quantity produced with respect to the number of jurisdictions was 0.0385 in the short run and 0.0822 in the medium run. The estimated price elasticity of demand was around 2.3 in both the short and medium run.

Are the empirical estimates broadly consistent with the model's predictions from Equations (3) and (4)? In the beginning of our period (2001), we have 116 districts in 21 provinces who are producing logs, so on average we have $n=5.5$. Substituting the empirical elasticity estimates and the number of districts into Equation (4) suggests that the semi-elasticity of quantity with respect to the number of districts $\left(\frac{1}{Q} \frac{d Q}{d n}\right)$ should be approximately 
0.034. Empirically, we estimate using the satellite data that $\frac{1}{Q} \frac{d Q}{d n}$ is 0.038 in the short run and 0.082 in the medium run. The short-run estimate exactly matches the theoretical prediction, and more generally, these estimates are of the same order of magnitude as that predicted by the theory.

Checking the other prediction-the prediction about the markup in Equation (3)-is necessarily more speculative, since we do not observe the markup directly. Substituting our estimates into Equation (3) and assuming that the $\frac{\pi^{\prime} r}{p}$ term is small suggests that the markup $\left(\frac{(p-c)}{p}\right)$ should be around 0.08 .

How can we estimate the markup in practice? One way to gauge the markup is to look at the bribes charged by corrupt officials who determine $q_{d}$. As discussed in Section III.B, within a district, there are many small firms who are willing to fell wood illegally, but they must bribe district officials to obtain an illegal transport permit to do so. Suppose that the district sells $q_{d}$ illegal log transport permits to these small firms in return for bribes. In equilibrium, as already shown, the firms will be willing to pay up to the full markup, $p-c$, in the form of bribes $b$.

How large are the bribes $b$ in practice? Direct estimates are scant, but based on fieldwork in Kalimantan, Casson and Obidzinski (2002) estimate that they are a relatively small share of the total price, consistent with what Equation (3) would suggest. Specifically, they estimate that in one district the bribe to receive an illegal wood transport permit is $\$ 22 / \mathrm{m}^{3}$ of wood. They also note that district officials only require sawmills to purchase these illegal permits for $20 \%$ of the wood they process, so the effective bribe required is about $\$ 4 / \mathrm{m}^{3}$. Because wood prices vary from $\$ 120$ to $\$ 250 / \mathrm{m}^{3}$, the bribes are equal to between 0.01 and 0.03 of the total price of the wood. This is only the transport permit: there are also (presumably) additional bribes to fell the wood. If the additional bribes are similar in magnitude, that would mean that the total bribe is between 0.02 to 0.06 of the total price of the wood. In a second district that they study, the district government levies official "fees" on illegal timber of about $\$ 20 / \mathrm{m}^{3}$, or between 0.08 and 0.16 of the total price. Although in this second case the fees go to the district treasury, they mention that district officials get some return from collecting these fees in the form of higher popularity with their constituents. Although these data are admittedly very rough, they suggest that the bribes collected are quite small as a share 
of the total value of the wood, and are on the same rough order of magnitude as the 0.08 range predicted by the theory.

\section{IV.E. Alternative Explanations}

The results in this section suggest that having more political jurisdictions is associated with an increased rate of deforestation and lower prices in wood markets. Although we have focused on Cournot competition between districts as one plausible interpretation of these findings, there are several alternative explanations as well. This section considers several of these alternative explanations.

1. Enforcement. One possible alternative explanation is that the creation of a new district could result temporarily in a decline in enforcement capacity as a new district government sets up its own district forest office. There are, however, several pieces of evidence against the idea that decline in enforcement is driving the results. First, if enforcement was the issue, we would expect that there would be a large increase in deforestation initially, with declines over time as the new districts established themselves. Instead, we see an initial increase in deforestation that is sustained over time so that the net effect after three years tends to be bigger than the immediate effect (contrast Panels A and $\mathrm{B}$ in Tables IV and V).

Second, we can test whether the increase in deforestation is greater in the new part of the district (i.e., the part that will be governed from a new district capital) as opposed to the old part of the district (i.e., the part that will be governed by the original presplit forest capital). If enforcement was driving the results, we would expect the increase in deforestation to be greater in the new part, but if it was driven by Cournot forces, we would not expect differential results between the old and new parts. In results shown in Online Appendix Table A.13, we show that there is little differential impact between the new and old parts of the district. Combined, these results suggest that a decline in enforcement due to the creation of a new district is unlikely to be driving the results.

2. Changes in the Assignment of Central Logging Quotas. As discussed, the amount of legal logging is determined by a 
negotiation between the districts and the center. One could imagine that in such a negotiation, increasing the number of districts in a province could increase that province's bargaining power, so that the province as a whole receives a higher legal quota.

Though this explanation could explain changes in the Production and Conversion zones, for illegal logging, however, this negotiation force should not be present. As shown in Table IV, we find increases in the rate of deforestation of approximately equal magnitude in the land use zones where logging could be legal or illegal (Production and Conversion) and the zone where no logging should take place (Conservation and Protection). Our results are therefore more consistent with district governments exerting control over both illegal and legal extraction of wood in provincial wood markets.

Moreover, in Production zones, legal logging is the selective felling of individual trees, not the type of clearing of 250 meter by 250 meter pixels that should appear in our MODIS satellite data. While these reallocations of legal logging quotas may be taking place, they do not seem to be the main driver of these results.

\section{IV.F Discussion}

On net, the results in this section suggest that increasing the number of districts increases the rate of deforestation, as would be predicted by a Cournot-style model of competition between districts. Although we cannot rule out all possible stories, several points of evidence provide suggestive evidence in favor of the Cournot-type story compared to alternative explanations. First, the fact that increasing jurisdictions not only increases quantities but also reduces prices confirms that there is to some degree a downward-sloping demand curve for logs in each province. Second, the fact that this occurs in zones where all logging is illegal suggests that this is not merely an artifact of changing allocation rules from the central government. Third, the fact that the impact of new jurisdictions on deforestation rates increases over time, rather than decreases, and the fact that deforestation is not more likely to occur in the new part of the district suggest that declines in enforcement in the illegal logging zones are not primarily driving the results. Finally, a back-of-theenvelope calculation suggests that the quantitative impact of increased political jurisdictions on deforestation is consistent 
with what one would expect from a simple Cournot model given the equilibrium elasticities observed in the data.

\section{SUBSTITUTES OR COMPLEMENTS? LOGGING VERSUS OTHER POTENTIAL SOURCES OF RENTS}

\section{V.A. Empirical Implementation}

An important question in the economics of corruption is how corrupt officials with multiple opportunities for rent extraction respond if one type of corruption becomes harder or easier. If corrupt officials behaved like classical profit-maximizing firms, and there were no spillovers from one type of corrupt activity to the other, then they would optimize separately on each dimension, and there would be no impact of a change in one type of corruption opportunity on the other type of corruption.

More generally, however, one could imagine effects in either direction. If corrupt officials worry about being detected, and if being detected means the official loses both types of corruption opportunities, then the two types of corruption will appear to be substitutes, and increasing corruption opportunities on one dimension will lower them on the other dimension. On the other hand, if there are fixed costs of being corrupt (for example, those with a low disutility from being corrupt selecting into the civil service), multiple corruption opportunities could be complements.

The two existing studies that have examined this question empirically (Olken 2007; Niehaus and Sukhtankar 2009) have both found evidence that alternative forms of corruption appear to be substitutes in the short run. Our setting allows us to examine both the short and medium run. If the fixed costs of corruption are important, adjustment may take time, and the short- and medium-run effects could be quite different.

We examine this question by considering how logging responds to changes in another source of local rents for district governments: oil and gas revenues. As discussed, a share of central oil and gas royalties is rebated back to districts, with half of the rebate going to the district that produces the oil and gas and the other half of the rebate being shared equally among all other districts in the same province. The amount of oil and gas revenue allocated to each district varies substantially over time as production fluctuates, prices change, and district boundaries change. 
Oil and gas revenue sharing can amount to a substantial amount of revenue-as much as US\$729.63 per capita in the highest district-which can in turn be a tempting source of rents for district officials. ${ }^{19}$ The idea that oil revenues are a source of illegal rents is consistent with findings from other contexts (e.g., Brollo et al. 2009; Caselli and Michaels 2009).

To examine the short-run impact of oil and gas rents on illegal logging we estimate a district-level regression. Since district splits influence oil and gas prices through the sharing formula, we control for district splits directly, and estimate the following equation:

$$
\begin{aligned}
\mathbf{E}\left(\text { deforest }_{d i t}\right)= & \mu_{d i} \exp (\beta \text { PCOilandGas } \\
& +\gamma \text { Nit } \\
& \text { umdistricts } \left._{d i t}+\eta_{i t}\right)
\end{aligned}
$$

where PCOilandGas dit $_{\text {is }}$ the per-capita oil and gas revenue received by the district (in US\$). Note that in computing Numdistricts $_{\text {dit }}$ when estimating (7), we count a district as having split only when it reports receiving its own oil and gas revenue. ${ }^{20}$ Each observation is a district (using the 2008 borders) $\times$ forest zone $\times$ year. In this equation, $\mu_{d i}$ is a district fixed effect and $\eta_{i t}$ is an island $\times$ year fixed effect. We report robust standard errors adjusted for clustering at the 1990 district boundaries. ${ }^{21}$ Since district oil and gas sharing revenue is, on average, 20 times

19. District government officials have recently been exposed in a wide variety of strategies to capture rents from the oil and gas revenue sharing fund. In Kabupaten Kutai Kartanegara, East Kalimantan, for example, the national Anti-Corruption Commission documented that in 2001 the district head issued a decree giving himself, top district government officials, and district parliamentarians an official monthly stipend equal to $3 \%$ of the amount the government received in oil and gas revenue, amounting to over US\$9 million over a four-year period (KaltimPost 2009 a,b). In Kabupaten Natuna, Sumatra, a former district head was arrested in 2009 by the Anti-Corruption Commission for allegedly embezzling US $\$ 8$ million in oil and gas revenue funds by appropriating the funds to a fake committee that he never set up (Kompas 2009). In Kabupaten Karawang, West Java, in 2004 the district head allegedly simply deposited US $\$ 600,000$ in oil and gas revenue sharing funds into his personal account rather than the district treasury (KoranTempo 2006).

20. As described above, de facto establishment of a district takes one to three years after the official de jure implementation. Since we care about district splits in this case because they affect the oil and gas allocation formula, it is important to control here for the de facto date the district split took effect, as that is the date the oil and gas formula would be affected.

21. We also show, in Online Appendix Table A.14, that our results are robust to clustering by province. 
larger than that generated by the forestry sector, one would not expect forestry decisions to influence oil and gas choices, so we would expect oil and gas revenue to be exogenous with respect to deforestation. ${ }^{22}$ To examine the medium-run impacts of oil and gas rents on illegal logging, we estimate (7) as before, but include three lags of PCOilandGas ${ }_{\text {dit }} .{ }^{23}$

\section{V.B. Results}

The results from estimating Equation (7) are shown in Table VI. Panel A, which shows the immediate impact effect of oil and gas revenue on logging, confirms evidence of short-run substitution between deforestation and oil and gas rents. Specifically, each US $\$ 1$ of per-capita oil and gas rents received by the district reduces logging by $0.3 \%$. These effects are found in both the legal logging zones $(0.3 \%$ in Production/Conversion; column (2)) and in the illegal logging zones $(0.6 \%$ in the Conservation/Protection zones). To interpret the magnitudes, note that the standard deviation of PCOilandGas dit $_{\text {after remov- }}$ ing district fixed effects is 23.7; so a one standard deviation change in PCOilandGas ${ }_{\text {dit }}$ decreases deforestation by $7.1 \%$ in the Production/Conversion zones and by $14.2 \%$ in the Conservation/Protection zones. ${ }^{24}$

22. On average, oil and gas revenues shared with districts are about $1 \%$ of district-level GDP; for non-producing districts (where we observe identical effects), they are about $0.5 \%$ of GDP. Fluctuations in these revenues are therefore even smaller than that. These revenues are thus large as a share of the government budget, but small compared with overall GDP, and so the impact-particularly on illegal logging-seems likely to occur through the arrival of rents from oil and gas exploitation.

23. Note that we do not have district-level data for PCOilandGas prior to 2001, so there is a question of how to assign lag values of PCOilandGas in the early years of our sample. Prior to the new revenue sharing rules taking effect in 2001, there was very little of this type of revenue sharing with districts. For example, in 2000 (prior to decentralization), for all of Indonesia, the total for all royalties (oil and gas plus other revenue sharing) shared with districts was 538 billion rupiah. In 2001, the first year of the new revenue sharing regime, it was 9,312 billion rupiah. Given that total revenue sharing prior to 2001 was less than $5 \%$ of the value in 2001 and after, we assume that oil and gas revenue was 0 prior to 2001 in computing lags. Using missing values for these lags instead produces qualitatively similar results in aggregate, though the reversal between short and long run is now limited only to the Production/Conversion zone (see Online Appendix Table A.17).

24. One might be concerned that these effects reflect labor market substitution, as labor moves into the oil production sector when prices are high. However, we have verified that the same results hold separately both for oil producers and 


\section{TABLE VI}

Substitutes or Complements? Effects of District-Level Oil and Gas Revenues on Deforestation as Measured with Satellite Data

\begin{tabular}{lccc}
\hline \hline & $(1)$ & $\begin{array}{c}(2) \\
\text { Production/ } \\
\text { Conversion }\end{array}$ & $\begin{array}{c}(3) \\
\text { Conservation/ } \\
\text { Protection }\end{array}$ \\
Variables & All forest & & \\
\hline Panel A & & $-0.00284^{*}$ & $-0.00597^{* *}$ \\
Oil and gas revenue & $-0.00316^{* *}$ & $(0.00165)$ & $(0.00252)$ \\
per capita & $(0.00160)$ & 3064 & 3400 \\
Observations & 6464 & & $-0.0113^{* * *}$ \\
Panel B: lags & & $-0.00432^{* *}$ & $(0.00190)$ \\
Oil and gas revenue & $-0.00492^{* * *}$ & $8.87 \mathrm{e}-05$ & $0.00561^{* * *}$ \\
per capita & $(0.00186)$ & $(0.00126)$ & $(0.00113)$ \\
Lag 1 & 0.000652 & 0.00132 & 0.000731 \\
& $(0.00103)$ & $(0.00151)$ & $(0.00138)$ \\
Lag 2 & 0.00112 & $0.00530^{* * *}$ & 0.00574 \\
& $(0.00130)$ & $(0.00160)$ & $(0.00372)$ \\
Lag 3 & $0.00519 * * *$ & 0.00240 & 0.000768 \\
& $(0.00163)$ & $(0.00154)$ & $(0.00195)$ \\
Sum of L0-L3 & 0.00205 & $<0.001$ & $<0.001$ \\
& $(0.00134)$ & $<0.001$ & $<0.001$ \\
Joint p & $<0.001$ & & 3400 \\
Sum of L0-L3 = L0 & $<0.001$ & 3064 & \\
effect $p$-value & & & \\
Observations & 6464 & &
\end{tabular}

Notes. The forest data set has been constructed from MODIS satellite images, as described in Section III.C. The Production and Conversion zones are those in which legal logging can take place, while the Conservation and Protection zones are those in which all logging is illegal. The dependent variable is the number of forest cells deforested in the district-zone-year. A unit of observation is a 1990-borders districtforest zone. The oil and gas revenue per capita variable reports the value of per capita revenue from oil and gas extraction at the district level in U.S. dollars. A unit of observation is a 2008-borders district-forest zone. In Panel B, we include the oil and gas revenue variable and three lags of the oil and gas revenue variable; the coefficient reported as sum of L0-L3 is the sum of the coefficients on the oil and gas revenue variable and the first three lags. $p$-values are reported for tests of joint significance of the contemporaneous and lagged oil and gas revenue variables (joint p) and a test of whether the sum of the coefficients on the contemporaneous oil and gas revenue variable and the first three lags is equal to the contemporaneous coefficient (sum of L0-L3=L0). All regressions include district-by-forest zone and island-by-year fixed effects and the number of districts the 1990 district has split into by year $t$ (and three lags of this variable in Panel B), where a district is counted as having split when it reports receiving its own oil and gas revenue. Robust standard errors are clustered at the 1990 district boundaries and reported in parentheses. $* * *$ significant at 0.01 level, ** significant at 0.05 level, * significant at 0.1 level.

Panel B shows, however, that the short-run and medium-run effects are quite different. While the immediate effect of oil and gas revenue on logging is still negative $(0.5 \%$ per US $\$ 1$, Panel B, column (1)), the sum of the lags is now positive and statistically

non-oil producers, where the results for non-oil producers are driven only by the revenue sharing they receive from other oil-producing districts in the same province, suggesting this is not driven by labor market factors. 
insignificant. That is, after three years, the total medium-run effect of US $\$ 1$ of per-capita oil and gas rents is to increase logging by $0.2 \%$. Once again, this shift occurs equally in the legal logging zones $(0.2 \%$, column (2)) and illegal logging zones $(0.1 \%$, column (3)). Although none of these effects are statistically significant, we can reject the null hypothesis that the sum of the lags and the immediate effect are the same at the $1 \%$ level. This suggests that the short- and medium-run impacts are different, and in the medium run, oil and gas rents and rents from logging are no longer substitutes.

An important question is why the effects might change over time. One natural hypothesis is that the higher oil and gas rents attract a different type of politician to office who is more interested in rent extraction. These politicians would then extract more rents on all dimensions, both from the oil and gas sector and from forests. To investigate this hypothesis, we begin by interacting oil and gas revenues with a dummy that captures whether the new direct election for district heads has taken place, that is,

$$
\begin{aligned}
& \mathbf{E}\left(\text { deforest }_{\text {dit }}\right)= \\
& \mu_{d i} \exp \left(\begin{array}{c}
\beta \text { PCOilandGas } \\
+\phi \text { PCOit }_{\text {dit }}+\text { SPostElection }_{\text {dit }} \\
+ \text { PostElection }_{\text {dit }}+\gamma \text { Numdistricts }_{\text {dit }}+\eta_{i t}
\end{array}\right) .
\end{aligned}
$$

The key coefficient of interest is $\phi$, which captures how the coefficient on PCOilandGas changes after the direct election. We continue to control for NumDistricts as in equation (7).

The results are presented in Table VII. The results show that $\phi$ is positive, that is, the negative effect of oil and gas revenues on logging attenuates once the direct election is held. Specifically, the point estimates suggest that $35 \%$ of the substitution effect between oil and gas revenues and forest extraction disappears once the direct election is held. This provides suggestive evidence that the medium-term reversal in the negative oil and gas effect is mitigated through a change in the political equilibrium.

What about the political equilibrium might be changing? In results shown in Online Appendix Table A.15, we find that higher oil and gas revenues lead to fewer candidates running in the direct election, and instead lead to the new district head representing a larger coalition of parties, using data from Skoufias et al. (2010). We find no impact on the probability the incumbent is reelected. It is possible that these larger coalitions engage in 
TABLE VII

Effects of District-Level Oil and Gas Revenues on Deforestation before and AFTER DiReCt Elections

\begin{tabular}{lccc}
\hline \hline & $(1)$ & $\begin{array}{c}(2) \\
\text { Production/ } \\
\text { Conversion }\end{array}$ & $\begin{array}{c}(3) \\
\text { Conservation/ } \\
\text { Protection }\end{array}$ \\
Variables & All forest & $-0.00457^{* * *}$ & $-0.0122^{* * *}$ \\
\hline Oil and gas revenue & $-0.00523^{* * *}$ & & \\
$\quad$ per capita & $(0.00143)$ & $(0.00159)$ & $(0.00174)$ \\
& 0.0218 & 0.0240 & 0.0299 \\
Postelection & $(0.110)$ & $(0.118)$ & $(0.217)$ \\
& $0.00175^{*}$ & 0.00147 & $0.00517^{* * * *}$ \\
Oil and gas $\times$ Postelection & $(0.000989)$ & $(0.000976)$ & $(0.00180)$ \\
& $-0.00348^{* * *}$ & $-0.00310^{* *}$ & $-0.00698^{* * *}$ \\
Oil + Oil * Postelection & $(0.00129)$ & $(0.00140)$ & $(0.00134)$ \\
& 0.00128 & 0.0161 & $<0.001$ \\
$p$-value & 6403 & 3037 & 3366 \\
Observations & & & \\
\hline \hline
\end{tabular}

Notes. The forest data set has been constructed from MODIS satellite images, as described in Section III.C. The Production and Conversion zones are those in which legal logging can take place, while the Conservation and Protection zones are those in which all logging is illegal. The dependent variable is the number of forest cells deforested in the district-zone-year. A unit of observation is a 1990-borders districtforest zone. The oil and gas revenue per capita variable reports the value of per capita revenue from oil and gas extraction at the district level in U.S. dollars. A unit of observation is a 2008-borders district-forest zone. The postelection variable is a dummy capturing whether the new direct election for district heads has taken place. All regressions include district-by-forest zone and island-by-year fixed effects and the number of districts the 1990 district has split into by year $t$, where a district is counted as having split when it reports receiving its own oil and gas revenue. Robust standard errors are clustered at the 1990 district boundaries and reported in parentheses. *** significant at 0.01 level, *** significant at 0.05 level, * significant at 0.1 level.

more rent extraction because they have more people with whom to share the spoils of office. Consistent with this, we also find evidence that having fewer candidates or a larger coalition is associated with a greater increase in logging, though the effects are only statistically significant in some forest zones and only in some specifications (see Online Appendix Table A.16). Together, these results, as well as the results in Table VI and VII, suggest that the higher political rents lead to a change in the political equilibrium, which in turn undoes the short-run substitution between oil rents and forest extraction. The idea that oil rents affect outcomes by affecting who is in office echoes recent findings from Brazil (Brollo et al. 2009).

\section{CONCLUSIONS}

The world's tropical forests are rapidly disappearing and climate change and biodiversity concerns have made countering 
tropical deforestation a subject of global policy debate. In common with other natural resources that fall under national ownership, command-and-control systems for forests in tropical countries are typified by weak governance. Monitoring of local bureaucrats and politicians who de facto control forest extraction, including that which is not officially sanctioned, is often imperfect.

We show that the incentives that local politicians and bureaucrats face are a key determinant of rates of tropical deforestation. In line with predictions from a Cournot model, we demonstrate that as the number of jurisdictions within a provincial wood market increases, deforestation rises and prices fall. The availability of rents from oil and gas exploitation, in contrast, blunts the incentive to extract forest, though only in the short term. There is thus a clear parallel between the behavior of local governments and of firms, which are the typical focus of study in the industrial organization literature. As competition increases, due to new districts being created in provincial wood markets, districts respond very much as we would expect firms to do in a standard Cournot model, by increasing extraction as a means of maximizing rents in response to falling wood prices.

Our results also serve as a counterexample to those who argue that decentralization of control over natural resources in weakly governed tropical environments should enhance their conservation. There is a large and growing literature, for example, that argues that local communities may have stronger incentives to conserve forests relative to central government (see Somanathan, Prabhakar, and Mehta 2009 and Baland et al. 2010 for some interesting evidence on this issue). Our work suggests that where political jurisdictions are large enough to have some market power in wood markets, and where the political heads of these jurisdictions obtain rents from allowing illegal logging (but not necessarily from preserving forests for future generations), then subdividing these jurisdictions actually leads to more (not less) deforestation.

The results in this article confirm the idea that standard economic models can help explain illegal behavior. The flip side is that these same models also suggest how one can potentially counteract corruption. One option is to strengthen top-down monitoring and enforcement by, for example, increasing the probability of detection of illegal activity ( $\pi$ in our model), though here weak governance and limited fiscal resources devoted to conservation may hamper efforts to detect and punish those involved in 
illegal logging. Another option is to provide district governments with alternative sources of rents $(r)$-monies, for example, from REDD (Reducing Emissions from Deforestation and Forest Degradation) or PES (Payment for Environmental Services) schemes where district politicians and bureaucrats are, in effect, paid not to cut down tropical forest (see, e.g., Jack, Kousky, and Sims 2008).

What is clear from this article is that the failure to take into account (and adjust) the extraction incentives of local politicians and bureaucrats is likely to render ineffective efforts to conserve the last great areas of tropical forest in the world-in Indonesia, Brazil, and the Democratic Republic of Congo. Political economy factors and, in particular, the extraction incentives that local officials face will have to play a central part in the next wave of efforts to conserve natural resources like forests, fisheries and natural habitats more generally. Blunting the incentives of local politicians and bureaucrats to engage in illegal activities is likely to be central to these efforts.

\section{SUPPLEMENTARY MATERIAL}

An Online Appendix for this article can be found at QJE online (qje.oxfordjournals.org).

LONDON SCHOOL OF ECONOMICS

UNIVERSITY OF MARYLAND

MASSACHUSETTS INSTITUTE OF TECHNOLOGY

UNIVERSITY OF MARYLAND

THE WORLD BANK

\section{REFERENCES}

Baland, J., P. Bardhan, S. Das, and D. Mookherjee, "Forests to the People: Decentralization and Forest Degradation in the Indian Himalayas," World Development, 38, no. 11 (2010), 1642-1656.

Barber, C. V., "The Legal and Regulatory Framework and Forest Production in Indonesia," in Community Land Rights, Customary Law, and the Law of Timber Concessions in Indonesia's Forests: Legal Options and Alternatives in Designing the Commons, C. Zerner, ed., no. UFT/INS/065 in Forestry Studies report, chapter appendix (Jakarta, Indonesia: Ministry of Forestry/ FAO, Draft March 1990).

Barr, C., I. A. P. Resosudarmo, A. Dermawan, and B. Setiono, "Decentralization's Effects on Forest Concessions and Timber Production," In Decentralization of Forest Administration in Indonesia: Implications for Forest Sustainability, Economic Development and Community Livelihoods, ed. Barr, C., 
Resosudarmo, I. A. P., Dermawan, A., and McCarthy, J. (Bogor, Indonesia: Center for International Forestry Research, 2006), 87-107.

Becker, G., and G. Stigler, "Law Enforcement, Malfeasance, and Compensation of Enforcers," Journal of Legal Studies, 3, no. 1 (1974), 1-18.

Breiman, L., "Bagging Predictors," Machine Learning, 26 (1996), 123-140.

Brollo, F., T. Nannicini, R. Perotti, and G. Tabellini, "Federal Transfers, Corruption, and Political Selection: Evidence from Brazil," Working Paper, Bocconi University, 2009.

Burgess, R., M. Hansen, B. Olken, P. Potapov, and S. Sieber, "The Political Economy of Deforestation in the Tropics,"NBER Working Paper 17417, 2011.

Caselli, F., and G. Michaels, "Do Oil Windfalls Improve Living Standards? Evidence from Brazil," NBER Working Paper 15550, 2009.

Casson, A. Decentralisation of Policies Affecting Forests and Estate Crops in Kotawaringin Timur District, Central Kalimantan, Case Studies on Decentralisation and Forests in Indonesia 5. (Bogor, Indonesia: Center for International Forestry Research, 2001).

Casson, A., and K. Obidzinski, "From New Order to Regional Autonomy: Shifting Dynamics of 'Illegal' Logging in Kalimantan, Indonesia," World Development, 30 , no. 12 (2002), 2133-2151.

CIFOR, Generating Economic Growth, Rural Livelihoods, and Environmental Benefits from Indonesia's Forests: A Summary of Issues and Policy Options. Center for International Forestry Research, report prepared for the World Bank, 2004.

Fitrani, F., B. Hofman, and K. Kaiser, "Unity in Diversity? The Creation of New Local Governments in a Decentralising Indonesia," Bulletin of Indonesian Economic Studies, 41, no. 1 (2005), 57-79.

Foster, A. D., and M. R. Rosenzweig, "Economic Growth and the Rise of Forests," Quarterly Journal of Economics, 118 (2003), 601-637.

Hansen, M. C., and R. S. DeFries, "Detecting Long-term Global Forest Change Using Continuous Fields of Tree-Cover Maps from 8-km Advanced Very High Resolution Radiometer (AVHRR) Data for the Years 1982-99," Ecosystems, 7 (2004), 695-716.

Hansen, M. C., R. S. DeFries, J. R. G. Townshend, M. Carroll, C. DiMiceli, and R. A. Sohlberg, "Global Percent Tree Cover at a Spatial Resolution of 500 Meters: First Results of the MODIS Vegetation Continuous Fields Algorithm," Earth Interactions, 7, no. 10 (2003), 1-15.

Hansen, M. C., S. V. Stehman, P. V. Potapov, B. Arunarwati, F. Stolle, and K. Pittman, "Quantifying Changes in the Rates of Forest Clearing in Indonesia from 1990 to 2005 using Remotely Sensed Data Sets," Environmental Research Letters, 4, no. 3 (2009).

Hansen, M., J. Townshend, R. DeFries, and M. Carroll, "Estimation of Tree Cover Using MODIS Data at Global, Continental and Regional/Local Scales," International Journal of Remote Sensing, 26, no. 19 (2005), 4359-4380.

Hofman, B., and K. Kaiser, "The Making of the Big Bang and its Aftermath: A Political Economy Perspective," In Reforming Intergovernmental Fiscal Relations and the Rebuilding of Indonesia, ed. Alm, J., Jorge, M. V., and Indrawati, S. M.(Cheltenham, U.K.: Edward Elgar, 2004).

IPCC, Climate Change 2007: Synthesis Report, Contribution of Working Groups I, II, and III to the Fourth Assessment Report of the Intergovernmental Panel on Climate Change. (Geneva: IPCC, 2007).

Jack, B., C. Kousky, and K. Sims, "Designing Payments for Ecosystem Services: Lessons from Previous Experience with Incentive-Based Mechanisms," Proceedings of the National Academy of Sciences USA, 105, no. 28 (2008), 9465.

Jensen, J. Introductory Digital Image Processing. (New York: Prentice-Hall, 1995).

Kaltim Post, "Muspida Kukar Tak Kembalikan" (Conference of District Leaders Funds for Kutai Kartanegara Not Returned)," Kaltim Post, July 22, 2009. , "Anggota Dewan Juga Dapat Insentif Migas" (Local Parliament Members Also Received Oil and Gas Incentive)," Kaltim Post, July 23, 2009.

Kindermann, G., M. Obersteiner, B. Sohngen, J. Sathaye, K. Andrasko, E. Rametsteiner, B. Schlamadinger, S. Wunder, and R. Beach, "Global Cost 
Estimates of Reducing Carbon Emissions through Avoided Deforestation," Proceedings of the National Academy of Sciences USA, 105, no. 30 (2008), 10302-12307.

Kompas, "KPK Tahan Hamid Rizal" (Anti-Corruption Commission Arrests Hamid Rizal)," Kompas, October 12, 2009.

Koran Tempo, "Polisi Sidik Dugaan Korupsi Rp. 6.5 Milyar" (Police Allege Corruption of Rp. 6.5 Billion)," Koran Tempo, January 3, 2006.

Lewis, T. R., and R. Schmalensee, "On Oligopolistic Markets for Nonrenewable Natural Resources," Quarterly Journal of Economics, 95 (1980), 475-491.

Morjaria, A., "Is Democracy Detrimental for the Environment in Developing Countries? Micro-evidence from Kenya," Working Paper, Harvard University, 2012.

Nabuurs, G. J., O. Masera, K. Andrasko, P. Benitez-Ponce, R. Boer, M. Dutschke, E. El-siddig, J. Ford-Robertson, P. Frumhoff, T. Karjalainen, O. Krankina, W. A. Kurz, M. Matsumoto, W. Oyhantcabal, N. Ravindranath, M. J. Sanz Sanchez, and X. Zhang, "Forestry," in Climate Change 2007: Mitigation. Contribution of Working Group III to the Fourth Assessment Report of the Intergovernmental Panel on Climate Change, B. Metz, O. Davidson, P. Bosch, R. Dave, and L. A. Meyer, eds., chapter 9 (Cambridge: Cambridge University Press, 2007).

Niehaus, P., and S. Sukhtankar, "Corruption Dynamics: The Golden Goose Effect," BREAD Working Paper 223, 2009.

Olken, B. A., "Corruption and the Costs of Redistribution: Micro Evidence from Indonesia," Journal of Public Economics, 90, no. 4 (2006), 853-870.

- "Monitoring Corruption: Evidence from a Field Experiment in Indonesia," Journal of Political Economy, 115, no. 2 (2007), 200-249.

Olken, B. A., and P. Barron, "The Simple Economics of Extortion: Evidence from Trucking in Aceh," Journal of Political Economy, 117, no. 3 (2009), 417-452.

ROI, "Undang Undang Nomor 5 Tahun 1967 tentang Pokok-pokok Kehutanan (Basic Forestry Law)," Republic of Indonesia (1967).

Shleifer, A., and R. Vishny, "Corruption," Quarterly Journal of Economics, 108 (1993), 599-617.

Skoufias, E., A. Narayan, K. Kaiser, and B. Dasgupta, "Electoral Accountability, Fiscal Decentralization and Service Delivery in Indonesia," World Bank (2010).

Somanathan, E., R. Prabhakar, and B. Mehta, "Decentralization for CostEffective Conservation," Proceedings of the National Academy of Sciences USA, 106, no. 11 (2009), 4143.

Stern, N. Stern Review on the Economics of Climate Change. (London: U.K. Treasury 2006), available at http://apo.org.au/research/stern-revieweconomics-climate-change (accessed July 10, 2010).

Tucker, C. J., "Red and Photographic Infrared Linear Combinations for Monitoring Vegetation," Remote Sensing of Environment, 8 (1979), 127-150.

VerHoef, J. M., and P. L. Boveng, "Quasi-Poisson vs. Negative Binomial Regression: How Should We Model Overdispersed Count Data?," Ecology, 88, no. 11 (2007), 2766-2772.

Vermote, E. F., N. Z. El Saleous, and C. O. Justice, "Atmospheric Correction of MODIS Data in the Visible to Middle Infrared: First Results," Remote Sensing of Environment, 83 (2002), 97-111.

Wan, Z., Y. Zhang, Q. Zhang, and Z.-l. Li, "Validation of the Land Surface Temperature Products Retrieved from Terra Moderate Resolution Imaging Spectroradiometer Data," Remote Sensing of Environment, 83 (2002), $163-180$.

Wooldridge, J. M., "Distribution-Free Estimation of Some Nonlinear Panel Data Models," Journal of Econometrics, 90 (1999), 77-97. 